\title{
Geochemical Modeling: A Review
}

Everett A. Jenne

June 1981

Prepared for the

Office of Nuclear Waste Isolation under a Related Services Agreement with the U.S. Department of Energy under Contract DE-AC06-76RLO 1830

Pacific Northwest Laboratory Operated for the U.S. Department of Energy by Battelle Memorial Institute 
NOTICE

This report was prepared as an account of work sponsored by the United States Government. Neither the United States nor the Department of Energy. nor any of their employees, nor any of their contractors, subcontractors, or their employees. makes any warranty. express or implied, or assumes any legal liability or responsibility for the accuracy. completeness or usefulness of any information, apparatus, product or process disclosed, or represents that its use would not infringe privately owned rights.

The views. opinions and conclusions contained in this report are those of the contractor and do not necessarily represent those of the United States Government or the United States Department of Energy.

\author{
PACIFIC NORTHWEST LABORATORY \\ operated by \\ BATTELLE \\ for the \\ UNITED STATES DEPARTMENT OF ENERGY \\ Under Contract DE-AC06-76RLO 1830
}

\author{
Printed in the United States of America \\ Available from \\ National Technical Information Service \\ United States Department of Commerce \\ 5285 Port Royal Road \\ Springfield. Virginia 22151
}

Price: Printed Copy $\$$

$\therefore$ Microfiche $\$ 3.00$

NTIS

-Pages Selling Price

001-025 $\$ 4.00$

026.050 \$4.50

$051.075 \quad 55.25$

076. $100 \quad \$ 6.00$

$101-125 \quad \$ 6.50$

$126.150 \quad \$ 7.25$

$151.175 \quad \$ 8.00$

$176.200 \quad \$ 9.00$

$201-225 \quad \$ 9.25$

$226-250 \quad \$ 9.50$

251-275 $\$ 10.75$

$276-300 \quad \$ 11.00$ 
PNL -3574

UC -70

\section{5}

WASTE/ROCK INTERACTIONS TECHNOLOGY PROGRAM

GEOCHEMICAL MODELING: A REVIEW

Everett $A$. Jenne

June 1981

Prepared for the

Office of Nuclear Waste Isolation

Under a Related Services Agreement with the U.S. Department of Energy

Under Contract DE-AC06-76RL0 1830

Pacific Northwest Laboratory

Operated by Battelle Memorial Institute

Richland, Washington 99352 



\section{FOREWORD}

In mid-FY 1980, activities at Pacific Northwest Laboratory in geochemical model ing related to nuclear-waste isolation became the responsibility of the Waste/Rock Interactions Technology Program (WRIT). This action was taken to bring the experimentalists deriving solubility and nuclide adsorption data and the geochemical modelers in closer association to facilitate a comprehensive and integrated product. Prior efforts in geochemical modeling were within the Assessment of Effectiveness of Geologic Isolation Systems (AEGIS) Program. The main thrust of AEGIS has traditionally been computer modeling of ground-water hydrology, respository breach scenario identification and consequence analysis (see Geochemical Modeling of the Nuclear-Waste Repository System, Deutsch 1980, for past AEGIS efforts on geochemical modeling).

The initial step for the incorporation of geochemical modeling into WRIT is this comprehensive and widesweeping review of the extant geochemical models. Geochemical modeling relevant to specific interests and needs outside those of nuclear-waste isolation was included to provide a wider base of knowledge and a more general perspective. In this way, the review can provide a platform upon which to recommend new modeling activities.

Foreword written by Jeffrey Serne, WRIT Program Manager. 


\section{SUMMARY}

Geochemical models are integrative tools which have evolved rapidly during the last decade. They permit the generation of useful information from numerous data concerning the interaction between water and earth materials. Two general families of geochemical models presently exist. The ion speciation-solubility group of geochemical models contain submodels to first calculate a distribution of aqueous species and to secondly test the hypothes is that the water is near equilibrium with particular solid phases. These models may or may not calculate the adsorption of dissolved constituents and simulate the dissolution and precipitation (mass transfer) of solid phases. Another family of geochemical models, the reaction path models, simulates the stepwise precipitation of solid phases as a result of reacting specified amounts of water and rock. Reaction path models first perform an aqueous speciation of the dissolved constituents of the water, test solubility hypotheses, then perform the reaction path modeling.

The different families of geochemical models and the model series within these families each have their advantages. No single model has yet evolved which combines a set of intrinsic properties and peripheral features such that it could be recommended as "the" preferred geochemical model. Some of the models can be characterized as having data bases that are higher quality, more extensive, and more thoroughly documented than those of other models. A few models contain adsorption and/or mass transfer capabilities, and some are competent to model aqueous systems at el evated temperatures. The mass transfer models attempt to simulate the precipitation and dissolution of solid phases as a result of water of specified composition reacting with a given mineral, mineral assemblage, or rock of specific chemical composition under equilibrium conditions.

Geochemical models are extremely useful in identifying the geochemical processes regulating the concentration of dissolved constituents. Additionally, they have great potential for quantifying the effects of temperature, ion speciation, sorption, and solubility on the concentrations of dissolved constituents. These properties in turn greatly influence 
the mobility of dissolved constituents in the geo- and bio-spheres. Geochemical models can also be utilized in a sensitivity analysis mode to assist in assigning priorities among competing research needs and among additional chemical characterizations of water from field and laboratory studies. To facilitate such applications of geochemical models, various attributes, constraints, and limitations of several geochemical models are discussed.

Certain improvements in the present versions of these models would enhance their value and usefulness to applications in nuclear-waste isolation and other energy-related technologies. Mass-transfer calculations of limited extent are certainly within the capabilities of state-of-the-art models. However, the reaction path models require an expansion of their thermodynamic data bases and systematic validation before they are generally accepted. In addition to the conventional constraint of equilibrium conditions, a much needed improvement for mass transfer calculations is the capability to apply kinetic control to the processes of mineral precipitation and dissolution. Several potential applications of geochemical models require that their competence be increased to deal with: 1) elevated temperatures between 0 and $350^{\circ} \mathrm{C}$; 2) activity calculations for saline waters; and 3) solid solution of minor constituents with major constituents in various solid phases. Moreover, sorption calculations need to be interactive with the ion speciation submodel to maximize the value of both submodels and the applicability of the results to real world situations. A major increase in the applicability of geochemical models will also result from the addition of thermochemical data for additional elements, including the actinides, and solid phases, including metastable and amorphic compounds. However, the addition of each element and related group of aqueous complexes and solids to a model requires validation via the modeling of a variety of analyses of natural waters as well as the modeling of prior solubility studies. These validation procedures indicate if particular deficiencies exist in these data and ensure the adequacy of these additional thermodynamic data. 


\section{CONTENTS}

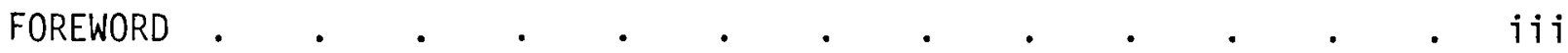

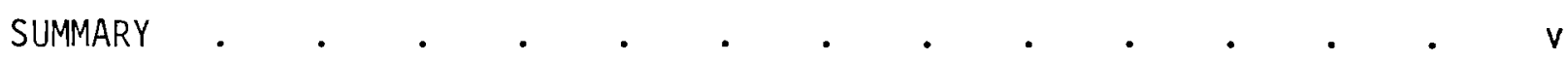

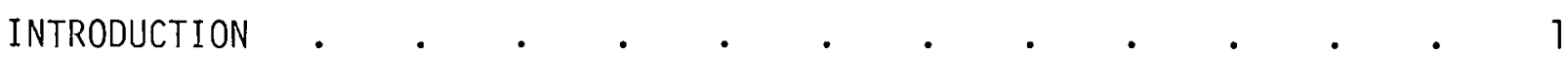

MODEL DEVELOPMENT

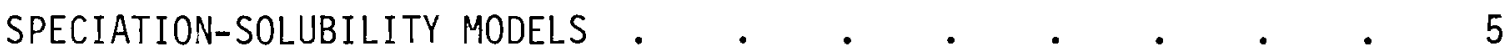

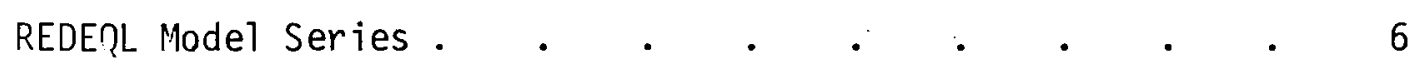

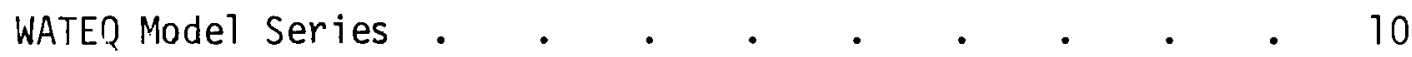

Other Speciation and Solubility Models . $\quad$. $\quad$ • $\quad$. 12

REACTION PATH MODELS $\quad$. $\quad$. . . . . . . . . . . 14

PATHCALC Model Series . . . . . . . . . . 14

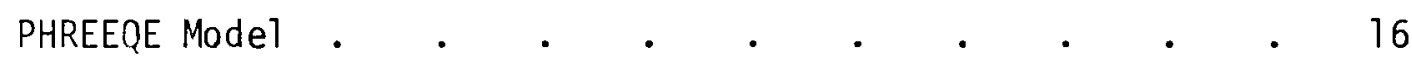

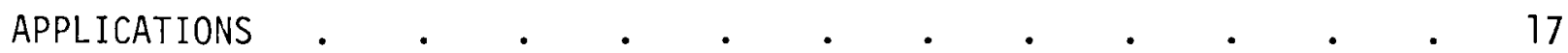

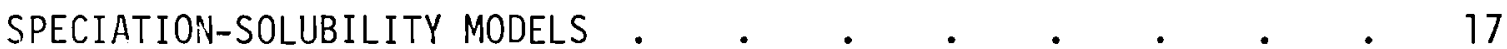

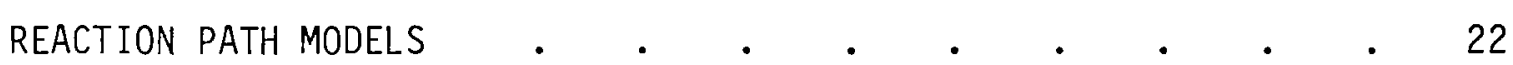

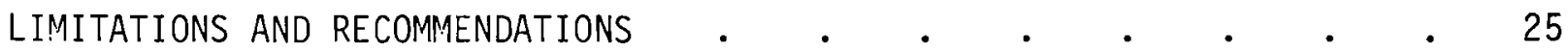

EQUILIBRIUM MODELS: SPECIATION-SOLUBILITY

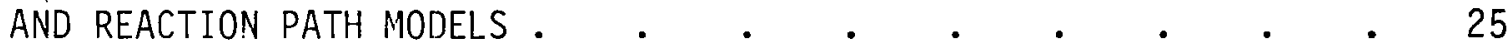

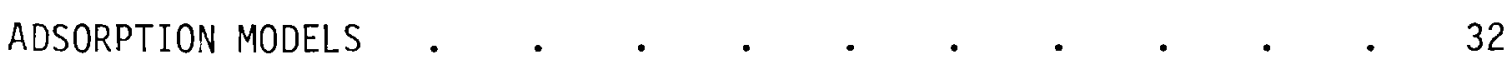

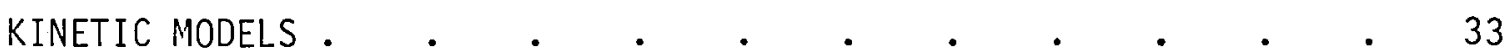

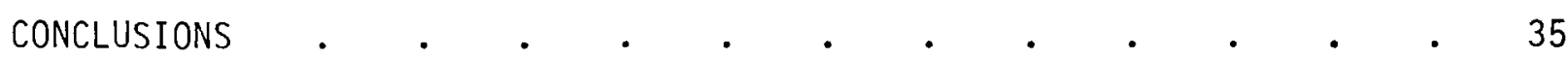

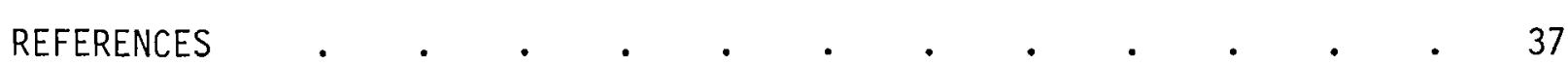

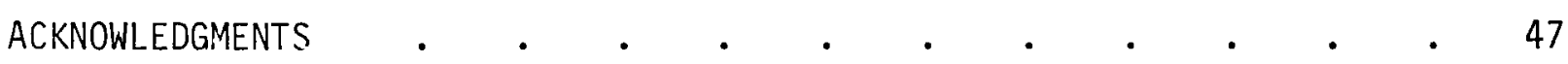





\section{INTRODUCTION}

A geochemical model is a theoretical construct used to predict certain properties of water containing dissolved electrolytes (Nordstrom, Plummer et al. 1979). It can help identify geochemical processes that regulate the concentration of dissolved constituents and may help quantify the effects of temperature, speciation, sorption and solubility on the concentrations of dissolved constituents. An understanding of these phenomena, when applied to issues of nuclear-waste disposal, can a id in the evaluation and the analys is of geochemical effects on a breached repository. Thus, it is a significant tool capable of intergrating a large amount of analytical data. A geochemical model can also assist in assigning priorities to the various research efforts required to 1 icense a repository by identifying those phenomena that present the major potential environmental hazards.

In general, geochemical models are of either two types: 1) the speciation-solubility models, or 2) reaction path models. A speciation submodel computes the activities of the uncomplexed, metal-solute species generally thought to possess primary biological potency (Jenne and Luoma 1977), although other cationic complexes may also possess biological potency (Magnuson, Harriss, Sun, Taylor, and Glass 1979). The solubility submodel tests the hypothesis that certain of the dissolved constituents in the water at its in situ temperature are in equilibrium with particular solid phases. Models testing this hypothesis, called speciation-solubility models, compute an estimate of the closeness to equilibrium of dissolved constituents and solid phases. Some of the speciation-solubility models also have submodels which compute mass transfer.

Speciation-solubility models with a mass transfer submodel solves directly for the final equilibrium state from the initial, specified conditions; i.e., the mass is transferred from an initial state to a final equilibrium state. The mass transfer is generally computed for a specified set of solid phases known from mineralogical observations to be those that dissolve and/or precipitate in a given environment. 
Reaction path models attempt to predict the resulting composition of a system when a quantity of water of given chemical composition reacts with a given quantity of a particular mineral or mineral assemblage.

A reaction path model solves for the final equilibrium state by working through the entire reaction process in iterative steps. Reaction path models use all solids in their data base whose free energies of reaction favor their dissolution or precipitation under equilibrium conditions.

This review discusses the basic concepts of extant geochemical models, describes major families of each type of models, and presents some information on applications of these models. The limitations and deficiencies of these geochemical models are also assessed. Conclusions and recommendations are made concerning further development of geochemical models. 


\section{MODEL DEVELOPMENT}

To predict the distribution of dissolved constituents in water, aqueous speciation models may be constructed using: 1) Bjerrum ionassociation theory; 2) Fuoss ion-association theory; or 3) Reilly, Wood and Robinson mixed electrolyte theory. Most computerized, speciation submodels use ion-association theory to calculate ion activity coefficients, which relate the thermodynamic activity of a species to its mass. Methods which utilize the equilibrium constant or the minimization of the Gibbs free energy, both being thermodynamically interrelated, are then used to determine the distribution of the aqueous species. Both approaches are subject to the constraints of mass balance and chemical equilibrium. Basically, the mass balance constraint requires that the sum of the uncomplexed element and its derived complexes equals the initial concentration of the element. The equilibrium constraint requires that the most stable (minimum Gibbs free energy) state be computed via the equilibrium constants for all mass action expressions or via Gibbs free energy values for all components and derived species. In some models, an additional constraint of charge balance is used in lieu of the mass balance of oxygen and hydrogen.

Both thermodynamic approaches state the problem numerically as one of finding a solution to a set of nonl inear equations. These mathematical techniques have already been reviewed by Wolery (1978) and Nordstrom, Plummer et a1. (1979), and discussed by Zeleznik and Gordon (1968) and von Zeggeren and Storey (1970). Possible nonunique solutions to the computational problem have been presented by 0thmer (1976) and Caram and Schriven (1976). Other reviews include that of Perrin (1977) on the applications of computers to analytical chemistry and of Leggett (1977) on machine computational efficiency.

All geochemical models minimally contain speciation and solubility submodels. The solubility submodel computes the ratio of the activity products, calculated in the speciation submodel, to the solubility of various solid phases. This ratio, the disequilibrium index, is an estimation of the closeness of each activity product to the solubility of the appropriate solid phase at equilibrium. 
One necessary consideration when using the solubility submodel is to determine whether the solid phase in question is controlling the concentration of one or more dissolved constituents. Depending on the adequacy of the data base, the submodel could indicate that the concentration of the dissolved constituents of interest could be limited or controlled by some other solid phase. In applying these models one must be aware that a limited supply rate of the constituent of interest could coincidentally produce a concentration similar to that resulting from equilibrium with the solid phase in question if too few samples are modeled. On the other hand, sampling and analytical errors can lead to the erroneous conclusion that the solid phase is not in equilibrium with the water, particularly when too few samples are modeled. Therefore, a number of aqueous samples are needed to permit objective conclusions as to the viability of the solubility limitation or control of a dissolved constituent by some solid phase. It follows that an affirmative answer from the solubility submodel is only permissive.

The speciation-solubility models describe an aqueous system under specified conditions. However, predicting the results of changes in solution composition or associated solid assemblage and their masses would sometimes be useful. This simulation is possible with the REDEQL and the MIX-PHREEQE families of geochemical models. The development and use of these geochemical models with mass transfer capability are limited by: 1) the nonequilibrium state of many natural mineral assemblages; 2) the lack of knowledge of reaction kinetics; 3) the difficulty of quantifying the mineralogy of solid phases involved in the modeling (particularly the amorphic compounds and highly substituted minerals); 4) the lack of thermodynamic data for many minerals of interest; and 5) the lack of knowledge of physical parameters for waters such as redox potentials and partial pressures of gases (such as $\mathrm{CO}_{2}$, particularly in deep aquifers).

The following sections describe briefly models that represent the various classes of geochemical models. The REDEQL and WATEQ families of speciation-solubility models are discussed in some detail in that they are the most widely used families of this class. The MIX-PHREEQE 
family includes speciation-solubility submodels with an emphasis on mass transfer capability. EQ3/6 is also discussed as a leading reaction path model.

\section{SPECIATION-SOLUBILITY MODELS}

Speciation-solubility models largely derive from the classical paper of Garrels and Thompson (1962) on speciation of major ions in sea water. Garrels and Thompson based their model on Bjerrum's ion-association theory. Their model included four cations ( $\mathrm{Na}, \mathrm{K}, \mathrm{Ca}$, and $\mathrm{Mg}$ ) and three anions $\left(\mathrm{SO}_{4}, \mathrm{HCO}_{3}\right.$, and $\left.\mathrm{CO}_{3}\right)$. They noted that these constituents, plus $\mathrm{Cl}$, account for more than 99 percent of the dissolved solids in sea water. The $\mathrm{Cl}$-complexes of the four cations were weak relative to those of the other three anions and were therefore omitted. Their computations indicated the following amounts of cations, as percentages of the total concentration, were present in the free state, $\mathrm{Na}=99, \mathrm{~K}=99, \mathrm{Ca}=91$, and $\mathrm{Mg}=87$ percent. Their calculated values for uncomplexed $\mathrm{Na}$ and $\mathrm{K}$ were confirmed by measurements with ion specific electrodes. Adams (1971), in a manner analogous to that of Garrels and Thompson (1962), demonstrated the computation of the activities of solute species and the general significance of ion pairing in soil solutions. 0ster and McNeal (1971) validated such an ion speciation model for soil solutions. They noted that, if one also accounts for the precipitation of gypsum and calcite as well as $\mathrm{Ca}-\mathrm{Na}$ exchange, the change in composition of soil solutions could be predicted as the moisture content decreased.

The equilibrium geochemical model WATCHEM, written by Ivan Barnes of the U.S. Geological Survey, was the first computerized, general purpose speciation-solubility model. It was used by Barnes and Clarke (1969) to address corrosion problems of well casings. This model spawned the WATEQ series of models (Truesdell and Jones 1973, 1974; P1 ummer, Jones and Truesdel1 1976; Ba11, Jenne and Nordstrom 1979; Ba11, Nordstrom and Jenne 1980; Ba11, Jenne and Cantrel1 1981) as well as WATSPEC (Wigley 1977), a mini version of WATEQ, and SOLMNEQ (Kharaka and Barnes 1973). The WATEQ model was constructed by Truesdell and Jones in the late 1960's, but was not published until 1973. Another major series 
of speciation-solubility models, known as REDEQL (Morel and Morgan 1972; McDuff and More1 1973; Morel, McDuff and Morgan 1973a, 1973b; Harriss, Magnuson, Taylor and Sun 1978; Vuceta and Morgan 1978; Ingle, Schudlt and Schults 1978) also served as the parent for the models MINEQL (Westa11, Zachary and Morel 1976) and GEOCHEM (Mattigod and Sposito 1979; Sposito and Mattigod 1979). In view of their widespread use, the families of REDEQL and WATEQ models are discussed in more detail al though other ion speciation and speciation-plus-solubility models are presented. REDEQL Model Series

The REDEQL model was initially oriented towards sanitary (environmental) engineering and towards instruction in laboratory research. The initial version (Morel and Morgan 1972) was followed a year later by REDEQL2 (McDuff and Morel 1973). This second version required less computer memory and had the capability to handle mixed metal and mixed ligand solids, e.g., $(\mathrm{Ca}, \mathrm{Mg})_{2} \mathrm{CO}_{3}$ and $\mathrm{Al}(\mathrm{OH})\left(\mathrm{SO}_{4}\right)$. Important attributes of the model are:

- mass transfer computations

- addition and/or modification of reactions by simply modifying the input card deck to include the reaction equation

- recomputation of speciation and solubility for a water analysis at preset changes in some parameter, such as a series of $\mathrm{pH}$ values

- adsorption treatment via James-Healy double layer model

- requirements of the computer code with respect to dynamic core memory are minimal by virtue of the mode of data input

- organic ligands with low molecular weights are included in data base for use in a sensitivity-analysis mode.

However, four principal criticisms of the REDEQL2 model are:

- lack of qual ity of the thermodynamic data base

- absence of data for many metastable, solid phases which are geochemically important, e.g., amorphic aluminosilicate compounds 
- $\quad$ lack of temperature correction for temperatures other than $25^{\circ} \mathrm{C}$

- absence of corrections for ionic strength.

To permit the application of REDEQL2 to sea water, Jackson and Morgan (1978) used the Davies equation to correct activity coefficients for increased ionic strength. However, it is not clear if the model was modified or if the activity coefficients were calculated external to the model. Additional upgrading of the REDEQL2 model has been undertaken at Stanford University, at the Environmental Protection Agency Laboratory at Corvallis, Oregon and at the University of Minnesota at Duluth with support from the Cincinnati Office of the Environmental Protection Agency. At Stanford University, uranium solutes and solids (Tripathi 1979), as well as the "Swiss" surface complex adsorption submodel (Davis and Leckie 1979), were added to the model. REDEQL2.EPA (Corvallis, Oregon) provides the capability of temperature compensation and contains some revisions of the thermodynamic data base (Ingle, Schuldt and Schults 1978). Investigators at the University of Minnesota at Duluth made a major effort to revise the thermodynamic data base of the REDEQL2 model (Harriss, Magnuson, Taylor and Sun 1978).

GEOCHEM, probably the most noteworthy version of the REDEQL series, was specifically modified for applications to soils (Mattigod and Sposito 1979). These investigators made extensive changes in the thermodynamic data base by adding "---a few hundred additional soluble complexes and solids---." By referencing previously published works, they suggest the competency of the model to estimate single ion activity coefficients for ionic strengths up to 3 molal. They have also introduced a new approach to the organic ligand problem and added a submodel for mass-action ionexchange.

The problem of organic ligands was addressed in the course of studies of the effects of sewage-sludge additions to soils (Mattigod and Sposito 1979). Detailed potentiometric titrations of the extracted soil solutions were completed, and then matched to the acid titration curve by using the appropriate amounts of up to six organic ligands which were present in the model and used to cover a range of association constants. 
GEOCHEM treats adsorption via either James-Healy double layer theory or mass action. Sposito, Page, Mattigod, Frink, Toben and Norris (1979) suggest that the latter may be more useful for largely reversible exchanges (macro concentrations) of ions. On the other hand, the former method may be applicable when small concentrations of ions interact at constant-potential solid surfaces with a significant component of irreversibility. The required input for the James-Healy adsorption submodel includes the number of adsorbing surface sites, the pH of the zero point of charge, dielectric constant, area of each adsorbing surface, and the contribution to the Gibbs free energy of adsorption from noncoulombic interactions. The authors of GEOCHEM state that the massaction exchange submodel "---applies only to monovalent and bivalent cations interacting with a montmorillonite surface." The thermodynamic data base for the mass-action exchange submodel is for the Camp Bertem montmorillonite, which has minimal substitution in the tetrahedral layer, and for the Chambers montmorillonite, which has substitution in both the tetrahedral and octahedral layers. The mass-action exchange submodel has three assumptions:

1) "the standard free energy of the reactions

$$
\begin{aligned}
& \mathrm{HX}(S, a q)=\mathrm{H}^{+}(\mathrm{aq})+X^{\top}(S, a q), \text { and } \\
& \mathrm{NaX}(S, a q)=\mathrm{Na}^{+}(a q)+X^{-1}(S, a q)
\end{aligned}
$$

is zero, where $(s, a q)$ denotes a homoionic montmorillonite or its anionic part in equilibrium with an aqueous electrolyte solution and $X$ refers to one equivalent of the anionic part of the montmorillonite" (Sposito, Page, Mattigod, Frink, Toben and Norris 1979).

2) "The standard free energy of formation of Na-montmorillonite may be calculated by a correlation technique of Mattigod and Sposito (1979)."

3) "The activity coefficients of $M X_{m}$ ( $M$ denotes the metal cation of valence $\mathrm{m}$ ) in a mixture of homoionic montmorillonites are always unity."

These investigators note that the reactions in above item 1 are equivalent to the assumption that $\mathrm{H}$ - and $\mathrm{Na}$-montmorillonites will be 
completely dissociated in equilibrium with an infinitely dilute solution. They also point out that these reactions are analogous to dissolution reactions and therefore the equilibrium constants are analogous to solubility product constants.

The GEOCHEM model still has certain 1 imitations of the original REDEQL model series. It is limited to the reference temperature of $25^{\circ} \mathrm{C}$ unless a user compiles and substitutes a new set of thermodynamic data valid for some other temperature. The model is also constrained to a set of 36 "metals" and 66 "ligands," 20 mixed metal and/or mixed 1 igand solids, and about 2000 solid phases. Each valence state of a metal and of a "ligand" (i.e., $\mathrm{NH}_{4}, \mathrm{NO}_{3}$ ) counts respectively as a separate metal and a separate "ligand." As in REDEQL2: 1) electroneutrality is not used as a constraint; 2) the user must specify which solids may form in the precipitation mode (Sposito, Page and Frink 1980); and 3) the partial pressure of $\mathrm{CO}_{2}$ must be specified in the "closed system" mode. Convergence is an occasional problem with the GEOCHEM model. For example, Sposito, Page and Frink (1980) note that in simulating the reaction of rainfall with soil minerals, they had to utilize acetate to model the complexation by organic carbon because the use of citrate led to convergence problems. It was also observed that low input concentrations sometimes produced difficulties with convergence (Sposito, Page, Mattigod, Frink, Toben, and Norris 1979).

The MINEQL model (Westa11, Zachary and Morel 1976) is another model in the REDEQL series which differs from REDEQL2 in four regards. MINEQL does not consider mixed metal or mixed ligand solids, does not treat adsorption and, most importantly, employs a charge balance equation rather than a fixed $\mathrm{pH}$ constraint. The charge balance is an internal constraint and, if analytical cation and anion inputs are not balanced, the model seeks a set of speciation values that minimizes deviation from charge balance. The mass balance and charge balance equations are both solved by a multidimensional Newton-Raphson routine. Bassett (1979) has generated a personal version of MINEQL which contains a number of organic ligands. 


\section{WATEQ Model Series}

Truesde11 and Jones $(1973,1974)$ constructed WATEQ speciationsolubility model while involved in studies of the geochemistry and mineralogy of saline lakes, as well as other natural water bodies. Thus, the thermodynamic data base of its solubility submodel contains data for a comprehensive group of saline minerals, along with other naturally occurring minerals. SOLMNEQ (Kharaka and Barnes 1973) was constructed from the earlier WATCHEM model (Barnes and Clarke 1969) as well as a prepublication version of WATEQ model. It is unique in that the model incorporates a pressure dependence in the $\log _{10} \mathrm{~K}_{r}^{\circ}$ values. The WATEQF model is a rewritten version of WATEQ, originaliy in PL/1, to the FORTRAN computer language and includes the addition of thermodynamic data for Mn solutes and solids (PIummer, Jones and Truesde11 1976). WATEQF also contains updated thermodynamic data, modified means of handling carbonate equilibria, and a change which allows for a back substitution method for convergence on anion mass balance, which decreases the number of required iterations.

These improvements were similarly incorporated into WATEQ2 by Ba11, Jenne and Nordstrom (1979) who retained, however, the PL/1 computer language for the code. The latter authors also added the trace elements $\mathrm{Ag}, \mathrm{As}, \mathrm{Cd}, \mathrm{Cs}, \mathrm{Cu}, \mathrm{Ni}, \mathrm{Pb}, \mathrm{Rb}, \mathrm{Zn}$, complexes of $\mathrm{Br}$ and $\mathrm{I}$, as well as polysulfides of $\mathrm{Ag}, \mathrm{Cu}$ and $\mathrm{Zn}$. (Thermodynamic data were not found for the polysuifides of other metals.) The WATEQ2 mode1 can accept input concentrations for two valence states for $A$ s and $F e$, and three valence states for both $\mathrm{N}$ and S. WATEQ3 (Ba11, Jenne and Cantre11 1981) accepts two valence states for $U$. The model performs valence speciation for a11 elements whose valence speciation is not provided as input, providing it is given an input redox potential or analytical values for $\mathrm{Fe}^{+2}$ and $\mathrm{Fe}^{+3}$ concentrations. It will use a computed redox potential only from the $\mathrm{Fe}^{+2} / \mathrm{Fe}^{+3}$ couple to calculate the speciation of other el ements.

The WATEQ2 geochemical model generally requires only two iterations for convergence of the speciation submodel. Moreover, WATEQ2 is the only model which accepts error estimates for the analyzed chemical 
constituents and for a selected group of solids computes a propagated, standard deviation appropriate to the stoichiometry of the solid phase. The model also carries and prints out the standard deviations for a 1 imited number of $\log _{10} \mathrm{~K}_{\mathrm{r}}^{\circ}$ values, which are generally the more recent data additions for which the original investigator provided error terms. An unusual feature of the WATEQ2 model is that it carries a number of alternative $\log _{10} \mathrm{~K}_{r}^{\circ}$ values which are designated as "maximum" $\log _{10} \mathrm{~K}_{r}^{\circ}$ or "minimum" $\log _{10} \mathrm{~K}_{r}^{\circ}$ values. If the thermodynamic data are uncertain, this feature permits ready evaluation of a possibile alternative thermochemical value which is a better estimate of the solubility of some solid phase than the "best" selected value.

The WATEQ2 geochemical model contains one sol id phase whose sto ichiometry is permitted to vary with the composition of the water. This amorphic aluminosilicate, allophane, has an $\mathrm{Al}: \mathrm{Si}$ ratio that varies with the $\mathrm{pH}$ of the water (Paces 1973a, b). The model also contains a number of metastable phases, such as two amorphic silica oxides, two allophane phases, melantherite, etc.

Regarding the competency of this model to handle elevated temperatures, WATEQ2 uses the Van't Hoff equation or, where available, analytical expressions for dependence of $\log _{10} \mathrm{~K}_{r}^{0}$ as a function of temperature. Hence, the reliability of this model can be expected to decrease progressively at temperatures above $100^{\circ} \mathrm{C}$. In contrast, SOLMNEQ (Kharaka and Barnes 1973) contains a table of equilibrium constants calculated at temperature increments between 0 to $350^{\circ} \mathrm{C}$ and interpolates between these increments for the actual value used in the modeling.

A number of "personalized" versions of the WATEQ model series are in use. Post-publication versions of SOLMNEQ, for example, include some organic acid ligands and ion-exchange equilibria. Boulegue and Michard (1979) added to a personal version of the WATEQF, the metal polysulfides for which association constants were available ( $\mathrm{Ag}, \mathrm{Cu}$ and $\mathrm{Zn}$ ). These polysulfides are the same species included in the WATEQ2 model. Donald Runnells and his students at the University of Colorado have added to their version of WATEQF, which is called WATEQFC (Runnells, Lindberg, 
Lueck and Markos 1980; Runne11s and Lindberg 1981), thermodynamic data for Mo, Se, Ra and Th as well as a chromatographic-plate adsorption submodel.

Other Speciation and Solubility Models

Some speciation models are specifically oriented to laboratory and theoretical studies. They are principally designed to compute speciation as a function of $\mathrm{pH}$ and concentration, and frequently only for the element of interest and one or two 1 igands. Early speciation models include the HALTAFALL model of Sillen and his colleagues (Ingri, Kakolowiez, Sillen and Warnquist 1967; Dyrssen, Jagner and Wengel in 1968), the EQBRAT model (Detar 1969), and the COMICS model (Perrin 1965; Perrin and Sayce 1967) which has gone through several modifications (Leggett 1977) including the recent version known as SIAS (Fardy and Sylva 1978). EQUIL (Fritz 1975) is a more recent, general purpose speciation-solubility model that uses a combination of matrix and iterative approaches to solve the set of mass balance equations. Other infrequently referenced models include SEAWAT (Lafon 1969), MIRE (Holdren 1977), IONPAIR and NOPAIR (Thrailkill 1970) and KATKHE (Van Breeman 1973). Finally, the SYSTAB model (MacCarthy and Smith 1979) should also be mentioned because it was developed to calculate formation constants of metal-organic complexes.

A special variety of speciation-solubility models have evolved for the marine environment using, for the most part, "conditional" stability constants (Kester, Bryne and Liang 1975; Bryne and Kester 1976). "Conditional" stability constants utilize concentrations rather than activity units, except for $\mathrm{H}$, and hence $\mathrm{OH}$, which are commonly but not always in activity units. Therefore, these conditional stability constant models do not incorporate adjustments for single ion activity coefficients to other ionic strengths. These models thus cannot be used at salinities significantly less than that of sea water which restricts the extention of these models to water in estuarine or fresh water environments.

Numerous papers discuss small speciation-solubility models, which are often written for a particular application. For certain chemical 
problems, small models of 1 imited scope may be adequate. For example, to evaluate the relative effectiveness of $\mathrm{Br}_{2}, \mathrm{Cl}_{2}$ and $\mathrm{I}_{2}$ as disinfectants, Rosenblatt, Meier and Small (1975) constructed a model to calculate the distribution of halogen species which result from the hydrolysis and redox reactions of these three elements at a fixed temperature, ionic strength, and water composition. Similarly, various small models have been written to calculate gypsum and sometimes calcite equilibria in soils (Dutt 1962; Dutt and Doneen 1963). A typical model of this type is that of Dufey, Petit, Goblet and Laudelout (1979), which contains one liquid phase (water), 13 solute species, a gas phase $\left(\mathrm{CO}_{2}\right)$, two solid phases (gypsum and calcite), and ion exchange among $\mathrm{Ca}, \mathrm{Mg}$ and $\mathrm{Na}$. Another example of a restricted model is that of Lindberg and Borno (1975) who wrote a model for a hand calculator to estimate the effect of acid or base additions upon the $\mathrm{pH}$ of natural and waste waters by taking into account the buffering capacity via dissociation constants.

Inconclusive results and sometimes erroneous conclusions ensue when models of 1 imited scope are used on aqueous solutions containing constituents which are important from a viewpoint of complexation but are not accounted for in the model. The fallacy of geochemical "models" which include only "important" reactions may be illustrated by an error of three orders of magnitude in the calculated solubility of $U$ for specified conditions which arose from the inadvertent omission of a single aqueous complex, namely $\mathrm{HF}$, from a geochemical model for $U$ (Langmuir 1978; Tripathi 1979). Similarly Pagenkopf (1978) reported that $A 1$ concentrations were 2 to 3 times that predicted from solubility of $\mathrm{Al}(\mathrm{OH})_{3}$ (crystalline) and considered that an amorphic, gibbsite precipitate was likely the reason. However, there are two potentially more important reasons for this probably erroneous conclusion. First, the text of Pagenkopf (1978) does not indicate whether any Al complex other than $\mathrm{Al}_{(\mathrm{OH})_{4}^{-}}$was considered. It is more likely that $\mathrm{SO}_{4}$ and other soluble hydroxide complexes account for the observed levels of dissolved Al rather than the formation of an amorphic, gibbsite precipitate. Further, there is no indication that the samples were filtered; hence, Al-containing, suspended sediment may have been present. Similarly, various samples were computed by Pagenkopf (1978) to be oversaturated 
with respect to the carbonates of the transition metals, possibly due to aqueous complexes of the transition metals, which were not taken into account. Other complexes of calcium and carbonate, as well as the possible presence of carbonate minerals in suspension, appear to have been ignored in these "solubility" calculations.

REACTION PATH MODELS

The other family of geochemical models is comprised of reaction path models. The true reaction path models transfer mass between one or more solids of stated chemical composition and the aqueous phase as a function of "reaction progress." Computationally, one unit of reaction progress means that one mole of a gaseous or sol id reactant has reacted with an aqueous system containing solid phases with which the aqueous phase is already at equilibrium. The chemical elements in the mole of added mass are distributed among possible soluble species by a speciation submodel. The most stable solid phases computed to be supersaturated in the aqueous phase are precipitated until supersaturation is el iminated and chemical equilibrium is again achieved between aqueous and solid phases. These models are generally run in one of two modes. In Mode I, a mineral is not allowed to dissolve once it has precipitated. In Mode II the precipitate may redissolve, i.e., reacting reversibly during subsequent reaction progress. Therefore, an early product formed in the second mode may disappear at a later stage of reaction progress. These computations are, of course, done without regard to activation energies and rates of precipitation or of dissolution because reaction path models are designed to compute the state of minimum free energy. PATHCALC Model Series

The original reaction path model, PATHCALC, was developed by $\mathrm{H} . \mathrm{C}$. Helgeson, his colleagues and students at Northwestern University (Helgeson 1968; 1971; Helgeson, Garrels and MacKenzie 1969; Helgeson, Brown, Nigrini and Jones 1970) from which derive EQUILIB (Shannon, Morrey and Smith 1977; Shannon and Lessor 1978), EQ3/6 (Wolery 1978; 1979) and FASTCALC (Kennecott, Inc., Salt Lake City), the latter being a stripped down version of PATHCALC. 
The PATHCALC model calculates the incremental equilibrium step by expanding the nonlinear expressions for equilibrium constants and solubility products into a second order Taylor series. This model integrates a set of ordinary differential equations obtained by differentiation of a related set of algebraic equations defining massbalance, charge, and mass-action relationships. Reaction progress proceeds via a large number of incremental steps. Because these stepwise solutions are approximate and consume a large amount of computer time, various users of this model have modified the calculation technique. Claude Herrick (Los Alamos National Laboratory, Los Alamos, NM) replaced the Taylor series technique with a predictor-corrector method described by Gear (1971a, b) resulting in greater computational efficiency (Miller, Pivinskii and Yamauchi 1977).

However, the use of the Gear high-order predictor integrators may result in considerable "drift" error during integration which requires additional code to correct. Besides modifying this approach to avoid the problem of drift error, wolery (1978) in EQ3/6 has added a set of semi-empirical algorithms for phase selection which permits the model to deal with mineral supersaturation and to improve the task of adding or deleting phases in the process of Gibbs free energy minimization. His EQ6 model permits reaction simulation at any temperature up to $300^{\circ} \mathrm{C}$, rather than at the eight predetermined temperatures of the earlier Helgeson model.

Another model of the PATHCALC family is EQUILIB $(a)$, which is proprietary to the Electric Power Research Institute of Palo Alto, CA. EQUILIB was specifically designed to be competent for geothermal fluids (Shannon, Morrey and Smith 1977; Shannon and Lessor 1978). An adjunct model, FLOSCAL, is the only model known to the author which utilizes a speciation-solubility model as input to a model with kinetic constraints on precipitation. It is designed to model the precipitation of silica, calcite and certain metal sulfides.

(a) This version was modified at Battelle, Pacific Northwest Laboratory by J. R. Morrey and D. W. Shannon with contributions from R. P. Smith and D. L. Lessor, whereas R. J. Robertus contributed to the adjunct kinetic precipitation model. 


\section{PHREEQE Model}

The documentation on a new reaction path geochemical model, PHREEQE, was received during the completion of this review. This model has been constructed by Parkhurst, Thorstenson and Plummer (1980), and follows the MIXI and MIX2 mass transfer models of Plurmer and associates (P1 ummer 1975; Plummer, Parkhurst and Kosiur 1975). Although related to the PATHCALC model which automatically determines the precipitating phases, PHREEQE differs markedly in that it requires the user to specify the reacting solids. The aqueous speciation submodel for PHREEQE is based on ion-association theory, but this can be modified by the user. In the mass balance computations, this model does not explicity include $\mathrm{H}$ and 0 . Instead, it permits calculation of $\mathrm{H}$ from the constraint of electrical neutrality, and calculation of $\mathrm{OH}$ from $\mathrm{H}$ as well as the dissociation constant of water. The thermodynamic data base of PHREEQE is largely that of WATEQ2 (Parkhurst, Thorstenson and Plummer 1980). 


\section{APPLICATIONS}

There are numerous potential applications of geochemical modeling for the understanding of basic geochemical processes and pollution potentials of solid wastes from the nuclear and fossil energy technology programs. It is just beginning to be recognized that these models are very useful in organizing extant data into useful information and in prioritizing present and subsequent research. An important use of computerized geochemical models which contain a maximum suite of elements and aqueous complexes is that of performing sensitivity analyses. In this mode, the speciation submodels can be used to determine the maximum error in the activity of uncomplexed cations and anions generated by the omission of some particular element from the analyses of the water sample. Such an application would help avoid possible erroneous conclusions concerning oversaturation with particular solid phases as demonstrated in an earlier example (e.g., Pagenkopf 1978). The absence of 1 igands, such as S(-II) which form strong complexes with metals, may be the cause of apparent oversaturation as shown by Jenne, Ball, Burchard, Vivit and Barks (1980). Used in a sensitivity analysis mode, the speciation-solubility models permit objective decisions on the value of obtaining analytical data for one ligand as opposed to another. If modeling is applied during the collection of the analytical data, the modeling results may indicate changes in the sampling density.

Because accurate thermochemical data are quite important, another application of geochemical models is to provide a basis for selecting among discordant thermochemical data (Nordstrom and Jenne 1977). This is facilitated by a geochemical model such as WATEQ2 which calculates solubility controls with up to two alternative thermodynamic values as well as with the selected value. This particular use of geochemical models may be a very important capability when geochemical modeling of the actinides is undertaken.

\section{SPECIATION-SOLUBILITY MODELS}

The speciation-solubility geochemical models may also be utilized in a predictive mode, drawing on available geochemical and mineralogical 
knowledge. Such an application was recently made by Sposito, Page and Frink (1980) to compute probable concentrations of $A 1$ and $F e$ in soil solutions as a result of acid rainfall in the northeastern U.S. Although they used a convoluted approach, in essence they determined the concentration of $A 1$ and $F e$ in acid rainfall following its reaction with amorphic gibbsite, $\mathrm{Al}(\mathrm{OH})_{3}$, and ferrihydrite, amorphic $\mathrm{Fe}(\mathrm{OH})_{3} \cdot \mathrm{A}$ related problem was addressed in an earlier study of the use of colorado River water for artificial recharge in the Coachella Valley of California (Jenne and Truesdel1 1973). In this study the Al level was set equal to its equilibrium solubility with crystalline gibbsite in surface and ground waters to evaluate the effect of mineral dissolution on dissolved solids from recharge through the unsaturated zone. In the study of Sposito, Page and Frink (1980) it would have been desirable to have included the level of dissolved $\mathrm{Si}$, as recent modeling ( $E$. A. Jenne, Battelle, Pacific Northwest Laboratory) indicates that the solubility of allophane, rather than gibbsite, frequently limits the solubility of $A 1$ during the initial reaction of rain with soils and other geologic materials.

The sophistication of speciation-solubility models and recent improvements in the thermochemical data base have reached the level where the solubility of some trace elements can be effectively modeled. A recent application of this capability has led to greater understanding of ore deposits and insight into processes that occur during in situ mining. Potter, Thompson, Clynne and Thurmond (1979) reported that kinetic and possibly chromatographic effects significantly modified solubility equilibria during in situ mining of $U$. Geochemical modeling, however, has not yet been applied to the problem of the environmental consequences of in situ, underground mining of U-ore bodies. Runnells, Lindberg, Lueck and Markos (1980) report that, using certain assumptions concerning the redox status, ground waters in the vicinity of a known ore body "--clearly define the location of the ore body" as evidenced by near equilibrium of the waters within the ore body with uraninite, $\mathrm{UO}_{2}$. This suggests the use of geochemical modeling as a valuable prospecting tool for metal ore deposits. 
Geochemical modeling of ground, mine, surface and tailings pile runoff waters in tri-state cadmium-lead mining district of the Missouri, OKlahoma and Kansas, indicated the following solubility limitations for trace elements: $\mathrm{BaSO}_{4}$ for $\mathrm{Ba}, \mathrm{CdCO}_{3}$ for $\mathrm{Cd}, \mathrm{ZnCO}_{3}$ and possibiy $\mathrm{ZnSiO}_{4}$ for $\mathrm{Zn}$, and rarely, $\mathrm{CaF}_{2}$ for $\mathrm{F}$, and $\mathrm{PbSO}_{4}$ for $\mathrm{Pb}$ (Jenne, Ball, Burchard, Vivit and Barks 1980). Furthermore, sensitivity analyses indicated that the concentrations of both $\mathrm{Pb}$ and $\mathrm{Mn}$ may have been 1 imited by the solubility of their phosphate compounds, $\mathrm{Pb}_{5} \mathrm{Cl}\left(\mathrm{PO}_{4}\right)_{3}$ and $\mathrm{MnHPO}_{4}$, respectively. Dissolved phosphate values were not obtained for the modeling study, so values used for these sensitivity analyses were taken from other sources for a creek in the area.

Solubility and its temperature dependence provides the basis for the $\mathrm{Na}-\mathrm{K}-\mathrm{Ca}$ geothermometer which is frequently utilized to estimate the temperature of hot water at depth. The temperature of geothermal waters is computed internally in the SOLMNEQ model (Kharaka and Barnes 1973) and in a plotting program which is an adjunct to WATEQ2 (Ball, Jenne and Nordstrom 1979).

One of the more important uses of geochemical models is to permit the interpretation of bioavailability and studies of acute toxicity of aqueous species. Similar modeling may also be applicable to investigations of chronic toxicity, although this reviewer is unaware of published reports on this subject. The principal evidence of the importance of speciation to the interpretation of bioavailability has been that it is the "free" (i.e., uncomplexed) metal ion that has biological potency (Jenne and Luoma 1977). Magnuson, Harriss, Sun, Taylor and Glass (1979) modeled solute speciation in the water used in a previous Daphnia magna toxicity study (Andrew, Biesinger and Glass 1977). Magnuson et al. reached the tentative conclusion that "the carbonate copper complexes are not toxic, the anionic hydroxo copper complexes contribute 15 to 18 percent to the toxicity of copper, and that free copper and/or the neutral and/or cationic hydroxy copper complexes are responsible for 60 to 70 percent of the toxicity in this set of experiments."

Although it is not generally recognized, speciation may be vital to an understanding as well as a quantitative description of the mechanisms 
for adsorption of ions onto inorganic substrates. For example, various studies show that the "half-adsorption" point varies markedly for the different elements as a function of $\mathrm{pH}$. The "conventional wisdom" among a subset of adsorption chemists for the last decade has been that the adsorption of first transition series metals is a function of the amount of the first hydrolysis product of the metal formed in solution. This is illustrated by the careful work of Fordham (1969) for Fe. His work shows that the percent adsorption onto kaolinite was a linear function of the calculated activity of $\mathrm{FeOH}^{+2}$ in solution below $\mathrm{pH} 2.7$. Between $\mathrm{pH} 2.7$ and 3.6, the adsorption data were partially linearized by plotting them against the activity of $\mathrm{Fe}(\mathrm{OH})_{2}^{+}$. In the more recent study of adsorption on kaolinite by Mattigod, Gibali and Page (1979), it was concluded that adsorption was a nearly 7 inear function of the activity of $\mathrm{Ni}^{+2}$. However, the very different slopes obtained in plots of $\mathrm{Ni}$ sorbed against the activity of $\mathrm{Ni}^{+2}$ from $\mathrm{NO}_{3}$ solutions, as opposed to $\mathrm{SO}_{4}$ solutions, suggest that the adsorption of positively charged, monovalent $\mathrm{Ni}$ species may also have major importance.

Published works of transport studies take 1 ittle account of speciation in computing retardation factors or distribution coefficients for aqueous species, in spite of the work of Fordham (1969) and of Mattigod, Gibali and Page (1979) showing the importance of speciation on absorption. "Water quality," hydrodynamic models often accommodate some nonconservative constituents, e.g., constituents which are permitted to increase or decrease during transport. For example, an early study (Dept. Science Ind. Res. 1964) of the Thames Estuary considered the formation of ammonia from organic nitrogen, its oxidation to $\mathrm{NO}_{3}$, and the oxidation of organic carbon, al1 as first order reactions. Thomann, O'Conner and Toro (1970) similarly used first order kinetics for the oxidation of $\mathrm{NO}_{2}$ and algal nitrogen, according to Williams and Hinwood (1976). In a hydrodynamic model of Westernport Bay, Australia, Williams and Hinwood (1976) included a "chemical kinetic and interaction" submodel which computes the oxidation of organic carbon and conversion of organic nitrogen to ammonia according to first order kinetics. Each of these processes is assumed to vary with temperature according to the relationship 


$$
k=k_{1} \theta^{\top}
$$

where $T$ is temperature and the values $k_{1}$ and $\theta$ are constants from the Thames Estuary Study (Dept. Science Ind. Res. 1964).

Few transport models permit even 1 imited chemical reactions al though precipitation in rare instances and adsorption occasionally are permitted. The inclusion of adsorption in the transport model is generally described by distribution coefficients. However, Rubin and James (1973) included adsorption via an adsorption isotherm in their unidirectional, steady state, flow model. In another case, adsorption was described in terms of a first order reaction which is equivalent to a constant ratio between the solution concentrations and the amount adsorbed, with a coefficient that may vary with the "rock type" in the aquifer (INTERA 1979). The Multicomponent Mass Transport model (Ahlstrom, Foote, Arnett, Cole and Serne 1977) for saturated and unsaturated transport in sediments utilizes PERCOL (Routson and Serne 1972) to model selected constituents present in macro concentrations: 1) the binary exchange reactions $\mathrm{Na}-\mathrm{K}, \mathrm{Na}-\mathrm{Ca}$ and $\mathrm{Mg}-\mathrm{Ca}$;2) one solute complex, $\mathrm{CaSO}_{4}^{\circ}$; and 3) two solid phases, gypsum, $\mathrm{CaSO}_{4} \cdot 2 \mathrm{H}_{2} \mathrm{O}$, and calcite, $\mathrm{CaCO}_{3}$. The Multicomponent Mass Transport model also utilizes PERCOL to model radionuclides sorption via a regression relationship of the $\mathrm{Sr}$ and $\mathrm{Cs}$ distribution coefficients with $\mathrm{Ca}, \mathrm{K}, \mathrm{Na}$ and $\mathrm{pH}$. The instream transport models SERATRA and FETRA (Onishi 1977; Onishi and Wise 1978; Onishi, 01 sen, Ambrose and Faleo 1979) have a dissolved contaminant submodel which handles sorption/desorption via distribution coefficients and contains a term for transfer rate between dissolved and sorbed states. These two models also permit radioactive decay and the degradation of dissolved organic compounds by five separate mechanisms.

Another area of future significance is that of using speciation modeling to improve age dating calculations. This capability may best be obtained with an additional submodel which would utilize existing speciation and solubility submodels and then provide tests of compatability of the various data. The pertinent study of Reardon and Fritz (1978) suggests the feasibility of this approach. 
REACTION PATH MODELS

There are few applications and validations of reaction path models. Wolery (1978) reported general agreement between mineralogical observations and reaction path simulation of basalt/sea water reactions using the EQ3/6 model. Benson, Carnahan, Apps, Mouton, Corrigan, Frisch and Shomura (1978) applied the FASTCALC reaction path model to the interaction of water with the Pomona member of the Columbia River basalts. They assumed that the basalt consisted primarily of glass which dissolved in water according to the following reaction:

$$
\begin{aligned}
& 0.55 \mathrm{SiO}_{2}+0.09 \mathrm{Al}_{2} \mathrm{O}_{3}+0.10 \mathrm{Fe} 0+0.12 \mathrm{MgO}+0.11 \mathrm{CaO}+ \\
& 0.025 \mathrm{Na}_{2} \mathrm{O}+0.005 \mathrm{~K}_{2} \mathrm{O}+1.26 \mathrm{H}+0.47 \mathrm{H}_{2} \mathrm{O}=0.55 \mathrm{H}_{4} \mathrm{SiO}_{4}+ \\
& 0.18 \mathrm{Al}+0.10 \mathrm{Fe}+0.12 \mathrm{Mg}+0.11 \mathrm{Ca}+0.05 \mathrm{Na}+0.01 \mathrm{~K} .
\end{aligned}
$$

The further assumption was made that the reactants were 0.1 mole of $\mathrm{CO}_{2}$ plus 0.9 mole of Pomona basalt. The reason for using this ratio of $\mathrm{CO}_{2}$ to basalt is unclear. Differences in the equilibrium mineral assemblage simulated for the open versus closed systems (Table 1) were attributed to the rather high $\mathrm{pH}$ value of 11 , calculated for the $\mathrm{CO}_{2}$-free system. Thus, the need for hard data in the setting of such parameters becomes obvious.

Benson, Carnahan, Apps, Mouton, Corrigan, Frisch and Shomura (1978, Table 11-14) reported another study in which ground waters of the Umtanum Formation in the Pasco Basin, which is within the Columbia River basalt province, were analyzed by the speciation-solubility submodels of both the FASTCALC and EQ3/6 models. These results (Table 2) show notable differences between the two models, which are primarily due to the large differences in the minerals included in the data bases of the two models. This suggests that the thermodynamic data base of the reaction path models must be significantly increased to give assurance that simulations with these models will be meaningful. Because of the sequential nature of the reaction path model calculations, the omission of one or more significant minerals from the data base can have a major effect on the results of these simulations. 
TABLE 1. Reaction Path Mass Transfer Simulation for Pomona Basalt With the FASTCALC Model for the Closed System Case (from Benson et a1. 1978, Table 9)

\section{Minerals}

calcite $\left(\mathrm{CaCO}_{3}\right)$

siderite $\left(\mathrm{FeCO}_{3}\right)$

talc $\left(\mathrm{Mg}_{3} \mathrm{Si}_{4} \mathrm{O}(\mathrm{OH})_{2}\right)$

kaol inite $\left(\mathrm{Al}_{2} \mathrm{Si}_{2} \mathrm{O}_{5}(\mathrm{OH})_{4}\right)$

montmorillonite-Ca ( $\mathrm{Ca} .165^{\mathrm{A} T_{2} .33}$
$\left.\mathrm{Si}_{3.67_{10}}(\mathrm{OH})_{2}\right)$

montmorillonite- $\mathrm{Na}\left(\mathrm{Na} .33^{\mathrm{A} T_{2}} .33\right.$
$\left.\mathrm{Si}_{3.67^{\mathrm{O}} \mathrm{O}_{0}(\mathrm{OH})_{2}}\right)$

tremolite $\left(\mathrm{Ca}_{2} \mathrm{Mg}_{5} \mathrm{Si}_{8} \mathrm{O}_{22}(\mathrm{OH})_{2}\right)$

prehnite $\left(\mathrm{Ca}_{2} \mathrm{Al}_{2} \mathrm{Si}_{3} \mathrm{O}_{10}(\mathrm{OH})_{2}\right)$

fayalite $\left(\mathrm{Fe}_{2} \mathrm{SiO}_{4}\right)$

laumontite $\left(\mathrm{CaAl}_{2} \mathrm{Si}_{4} \mathrm{O}_{8}(\mathrm{OH})_{8}\right)$

adularia $\left(\mathrm{KAlSi}_{3} \mathrm{O}_{8}\right)$

albite-low ( $\left.\mathrm{NaAlSi}_{3} \mathrm{O}_{8}\right)$

chlorite-Mg $\left(\mathrm{Mg}_{5} \mathrm{Al}{ }_{2} \mathrm{Si}_{3} \mathrm{O}_{10}(\mathrm{OH})_{8}\right)$

corundum $\left(\mathrm{AT}_{2} \mathrm{O}_{3}\right)$
Without $\mathrm{CO}_{2}$

With $\mathrm{CO}_{2}(\mathrm{a})$

$x(0.0016)$

$X(0.036)$

$x^{(c)}$

$x^{(c)}$

$x(0.534)$

$x(0.01483)$

$X(0.02950)$

$x(0.05)$

$x(0.0442)$

$\times(0.2133)$

$x(0.0006)$

$x(0.01)$

$x(0.009)$

$x(0.05)$

$X(0.0272)$

$x^{(d)}$

$x^{(d)}$

$x^{(d)}$

(a) Molar ratio of 9:1 of Pomona basalt:carbon dioxide.

(b) $X$ indicates the phase formed, the number in parenthesis is moles precipitated in the simulation.

(c) Listed as being formed in presence of $\mathrm{CO}_{2}$ (Benson et al. 1978, p. 10), but not 1 isted in terms of molar quantities formed in the presence of carbon dioxide (Benson et a1. 1978, p. 12). Table 9 in the cited reference indicates both were precipitated with carbonate present, but are later partially consumed. Table 9 also indicates that corundum is initially precipitated, but then dissolves partially.

(d) Transient product formed during initial reaction progress. 
TABLE 2. Minerals Calculated to be Oversaturated in Ground Water Models from Below the Umtanum Formation by Two Reaction Path Models, Presumably at $60^{\circ} \mathrm{C}$ (from Benson et al. 1978, Tables 11-15)

\section{FASTCALC}

corundum
gibbsite
sanidine-high
microcline
albite-low
anorthite
dickite
kaolinite
halloysite
talc
montmorillonite-Ca
montmorillonite-K
montmorillonite-Mg
montmorillonite- $\mathrm{Na}$
montmorillonite-25SW
chlorite-Mg
illite
muscovite
biotite
spinel
sillimanite
warrakite
zoesite
kyamite
adularia
andalusite
prehnite
laumontite

EQ6

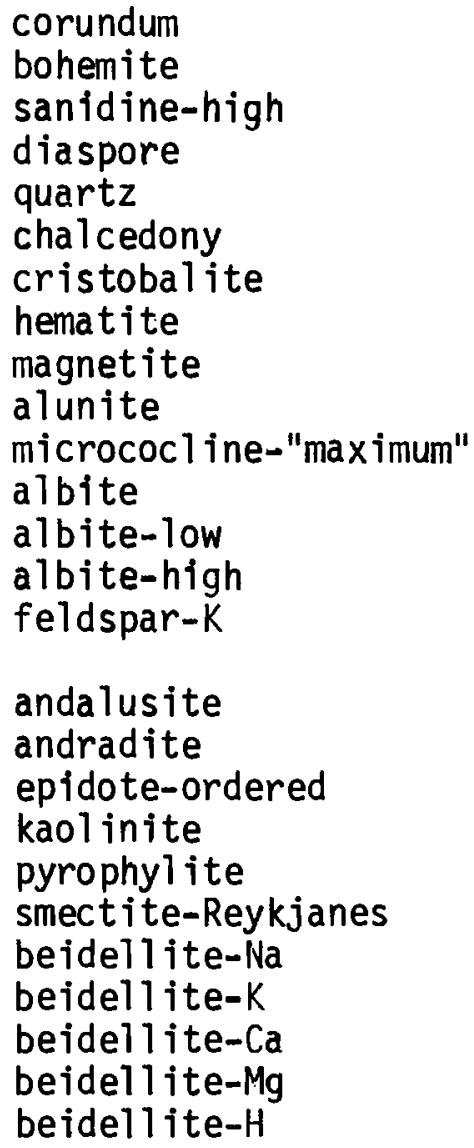




\section{LIMITATIONS AND RECOMMENDATIONS}

\section{EQUILIBRIUM MODELS: SPECIATION-SOLUBILITY AND REACTION PATH MODELS}

In general, the speciation-solubility and reaction path families of geochemical models need improved capabilities in their speciation, solubility, and adsorption submodels. Each of these areas limit the capabilities of the current models in addressing pertinent geochemical problems. The 1 imitations discussed below principally derive from application needs in the nuclear and fossil fuel energy technologies. The relative importance of the various limitations of extant geochemical models depends upon the intended application, and any priority listing is overly dependent on one's individual perspective. However, the 1 imitations and deficiencies of equilibrium geochemical models fall into four general categories:

- inadequate theoretical understanding and formulation, e.g., activity coefficients over a wide range of ionic strengths, ion substitution in solids (solid solution), and redox potential

- inadequate critical evaluation of available thermodynamic data, and the lack of other data for particular solids and complexes, free energy and enthalpy as a function of temperatures and pressure

- incompetence of the models for particular applications in terms of elements, complexes and solids which have not been included in the models but for which thermodynamic data exists

- inadequacy of water analyses used, e.g., 1 imited number of constituents analyzed for, quality of data, especially the physicochemical parameters of deep aquifers, estimates of sampling and analytical errors.

With respect to a theoretical understanding, a significant 1 imitation of thermodynamic equilibrium models is the absence of an adequate theory of individual ion activities which would bridge the present theories of dilute and concentrated electrolyte solutions. Several 
approaches to this problem have been proposed (Whitfield 1975a,b; Marcus 1977; Potter and Haas 1978; Van Luik and Jurinak 1979). However, in each approach to resolving the activity coefficient problem, one encounters the dual problems of an inadequate theoretical framework to permit extrapolation over wide ranges in ionic strength and a lack of experimental data for a comprehensive suite of ions to permit adequate calculation of ion activities. Consequentiy, speciation-solubility modeling of many natural waters and complex aqueous solutions of intermediate ionic strength is difficult.

A general theory for ion substitution in solid phases (or "solid solution") is required for the equilibrium models which el iminates the need to experimentally determine the aqueous- and solid-concentration relationships for structurally identical solids with compositional variations. This capability would result in a major increase in the natural and polluted waters determined to have chemistries limited by the solubility of solid phases. Many solid compounds are members of a particular solid solution series, but, in the geochemical models, they are normally represented by an average stoichiometry or by specific endmember compositions. This may result in an apparent, but not real, departure from equilibrium for such solid solution minerals. In the WATEQ2 model, the only solid solution mineral whose stoichiometry is permitted to vary with the composition of the equilibrating water is the amorphic aluminosilicate, allophane. The importance of solid solution is indicated by the solubility of magnesium calcite, which varies by more than a factor of ten as the mole fraction of substituted $\mathrm{MgCO}_{3}$ ranges from 0 to 25 mole percent (Thorstenson and Plummer 1977). This variation in calcite solubility as a function of the $\mathrm{Mg} / \mathrm{Ca}$ ratio has recently been observed in a creek draining an area with some retorted oil shale (E. A. Jenne, A. Felmy, J. Zachara, T. Garland, and R. Wildung, Battelle, Pacific Northwest Laboratory). The reliable model ing of solubility controls will be markedly facilitated by the development of analytical expressions for the variation in solid-phase stoichiometry with solution-phase composition, in conjunction with analytical expressions of solubility as a function of its stoichiometry. The inability 
to account for solubility changes due to solid solution severely limits our capability to model secondary layer silicates, substituted manganese oxides, and apatites. Solid solution may be a major problem in the $150^{\circ} \mathrm{C}$ to $350^{\circ} \mathrm{C}$ temperature range.

The greatest error in speciation and, hence, solubility modeling of any element having multiple valence states is likely to be the problem of knowing the appropriate redox potential. Moreover, no theoretical basis exists for dealing with the observed disequilibrium among redox couples. The kinetics of redox reactions are often slow, resulting in disequilibrium between redox couples in the short term (Table 3). As evidenced previously (Table 4), it is meaningless to apply the redox potential calculated from one analytically determined redox couple to certain other couples in natural waters. However, because redox couples of interest are often analytically unaccessible (i.e., one or both valence states are below detection), meaningful redox speciation may not be presentiy possibie. Intensive studies of the kinetics of redox reactions between couples and of the extent of disequilibrium among couples in both the laboratory and field environments are urgently needed. The potential value of such studies is indicated by two observations. One is the finding of Nordstrom, Jenne and Bal1 (1979) that, if analytical concentrations of $F e(I I)$ and $F e(I I I)$ were corrected for complexation, the redox potentials calculated from the $\mathrm{Fe}^{+2} / \mathrm{Fe}^{+3}$ couple agreed quite well with the redox potential measured with the bright platinum electrode in acidic mine water drainage. The other pertinent observation is that both the $E_{P t}^{H}$ (platinum electrode potential referenced to the hydrogen electrode potential) and $E_{\mathrm{Fe}}^{\mathrm{H}}+2 /+3$ potentials may relate to the $\mathrm{Mn}^{+2} / \mathrm{Mn}^{+4}$ couple in well poised systems (Holdren 1977; E. A. Jenne, Battelle, Pacific Northwest Laboratory). One valuable aspect of the WATEQ2 and EQUILIB models is that all states of a multivalent element which are analytically accessible can be entered so there is no degradation of analytical, valence speciation information. The capability to accept input of analytical valence states for CU(I) and Mn(IV), however, have not been provided in WATEQ2 due to the lack of analytical data for these valence states of $\mathrm{Cu}$ and $\mathrm{Mn}$. Because $\mathrm{Mn}^{+4}$ is very insoluble and $\mathrm{Mn}^{+3}$ is highly unstable, it has not been possible to date to determine a Mn-redox couple analytically. 
TABLE 3. Evidence of Disequilibrium Among Redox Couples in Poorly Poised System (from Jenne, Girvin, Ball and Burchard 1978) Redox Couple $\mathrm{e}^{(\mathrm{a})}$ Redox Potential
$\mathrm{NO}_{3} / \mathrm{NO}_{2}$
440 to 430
Pt el ectrode
390 to 360
$\mathrm{NO}_{3} / \mathrm{NH}_{4}$
330 to 320
$\mathrm{Fe}^{+3} / \mathrm{Fe}^{+2}$
120 to 50
$\mathrm{SO}_{4} / \mathrm{S}^{-2}$
-170 to -200

(a) Calculated from analytical values except for the bright platinium electrode values; the samples were from San Francisco Bay, California ranging from minimum to near maximum salinity. Computed by an early version of WATEQ2.

TABLE 4. Log Activities of Particular Solute Species Computed by WATEQ2 Using the Various Redox Potentials for Valence Speciation (from Nordstrom et a1. 1979, Table XI)

\begin{tabular}{|c|c|c|c|c|c|}
\hline $\begin{array}{l}\text { Redox } \\
\text { Couple }\end{array}$ & $\begin{array}{r}\text { Redox }(a) \\
\text { Potential } \\
\end{array}$ & $\mathrm{Fe}^{+2}$ & $\mathrm{Fe}^{+3}$ & $\underline{\mathrm{H}}_{2} \underline{\mathrm{AsO}}_{3}^{\mathrm{O}}$ & $\mathrm{HAs}_{2} \mathrm{O}_{4}^{-2}$ \\
\hline & $-m v-$ & -- & $-\min v$ & $g$ activ & - - - \\
\hline $\mathrm{O}_{2} / \mathrm{H}_{2} \mathrm{O}$ & 793 & 17.89 & 17.25 & 38.03 & 7.60 \\
\hline $\mathrm{NO}_{3} / \mathrm{NO}_{2}$ & 445 & 11.87 & 17.25 & 25.98 & 7.60 \\
\hline Pt electrode & 440 & 11.78 & 17.25 & 25.80 & 7.60 \\
\hline $\mathrm{NO}_{3} / \mathrm{NH}_{4}$ & 328 & 9.78 & 17.25 & 21.81 & 7.60 \\
\hline $\mathrm{O}_{2} / \mathrm{H}_{2} \mathrm{O}_{2}$ & 141 & 6.81 & 17.61 & 15.14 & 7.60 \\
\hline $\mathrm{Fe}^{+3} / \mathrm{Fe}^{+2}$ & 73 & 6.58 & 18.50 & 12.72 & 7.60 \\
\hline $\mathrm{SO}_{4} / \mathrm{S}^{-2}$ & -532 & 6.56 & 29.36 & 7.59 & 24.04 \\
\hline
\end{tabular}

(a) Computed from analytical values from a low dissolved solids surface water. 
The adequacy of thermodynamic dato is an important 1 imitation to geochemical modeling both from the standpoint of missing data and of inaccurate data. Thermochemical data relating to the solubility of several key minerals and related solids are nonexistant, as in the case of data for several zeolites and substituted manganese oxides. Although estimation techniques permit the calculation of a Gibbs free energy of formation (Mattigod and Sposito 1978; Tardy and Garrels 1974), the reliability of this approach has generally not been determined except for layer silicates. One method to ascertain the reliability of avai1able thermodynamic data is to utilize a thermodynamic model, such as PHAS20, which solves a set of simultaneous regression equations such that the more reliable data are weighted according to the supplied error terms (Haas 1974; Haas and Fisher 1976). Application of this model to a particular solid requires that the PHAS20 model first be used to optimize the thermochemical data for each related aqueous and solid reactant and product. Although a very powerful tool, it has to date been applied only infrequently (Nordstrom and Jenne 1977; Potter 1977; Haas, Robinson and Hemingway 1980).

PHAS20 could assist in choosing among available but contradictory metal-1igand association constants, such as the second hydrolysis constant of Cu (Paulson 1978; 1980), which otherwise requires careful redetermination. Unfortunately, many papers and even PhD theses reporting these studies frequently do not provide sufficient information to permit adequate evaluation and/or recalculation of reported association constants. Other ion association constants also require determination or redetermination (Jenne 1979).

Although it is clear that complexation of metals by dissolved organic compounds is also of major importance in many waters (Jenne and Luoma 1977; Jenne 1977), a completely satisfactory way of dealing with this problem has not emerged. A simulation of the potentiometric titration curve of dissolved organic compounds by six organic ligands, as in the GEOCHEM model (Mattigod and Sposito 1979), appears to require the assumption that the complexation strength of dissolved organics for metals is strictly proportional to their complexation strength for $H$. 
There is a major need for association constants of various metal ions and natural, as well as synthetic, organic 1 igands.

Additional experimental data will also be required to reliably model water chemistries and water rock interactions at elevated temperatures. For example, when PATHCALC was used to estimate the saturation molality of $\mathrm{NaCl}$ as a function of temperature $\left(0\right.$ to $\left.300^{\circ} \mathrm{C}\right)$, the error ranged from plus 1 molal to minus 2 molal (Miller, Pivinskii and Yamauchi 1977). However, it must be borne in mind that lack of model competence in terms of missing complexes, such as $\mathrm{CaCl}^{+}$, appropriate to the $\mathrm{NaCl}$ example could be responsible for the apparent undersaturation or oversaturation. Wolery (1978, p. 62) has pointed out that an increase in the temperature of sea water to $300^{\circ} \mathrm{C}$ can cause a thousand-fold increase in the activity of $\mathrm{H}$ due to the change in various ion association constants with temperature.

Corrections for the pressure dependence of the equilibrium constants such as SOLMNEQ and EQ6 perform (Nordstrom, Plummer et a1. 1979) are required when geochemical models are applied to pressurized aquifers or to the deep ocean. Pressure corrections are especially pertinent to dissolved $\mathrm{CO}_{2}$ and equilibria with carbonate minerals.

Inadequate competency of extant geochemical models is probably a more serious limitation to useful modeling applications than is the inadequacy of thermodynamic data. This problem becomes apparent in the case of reaction path modeling. Benson, Carnahan, Apps, Mouton, Corrigan, Frisch, and Shomura (1978, p. 13) note that the results of the reaction path modeling of ground waters in the Umtanum formation were not in agreement with the alteration products observed in the Pasco Basin basalts. This was attributed to absence of some minerals observed in the basalts from the thermodynamic data bases of the reaction path models, EQ3/6 and FASTCALC. Of 28 minerals calculated by the FASTCALC model to be oversaturated in this ground water, only five of them were computed to be oversaturated by $\mathrm{EQ3/6}$. Thus, precipitation of $\mathrm{Ca}$, before calcite saturation occurred, was simulated by the FASTCALC model as laumontite, instead of heulandite plus clinoptilolite, the zeolites which naturally occur on the basalt fractures. Most of these differences are simply the result of different minerals in the data base. 
Geochemists using speciation-solubility models are usually aware of which minerals are likely to precipitate in a specified environment, given a state of oversaturation or equilibrium between the aqueous phase and solid phase in question. Other solid phases which compute to be oversaturated are usually disregarded. However, reaction path models are designed to compute the most stable phases based on the condition of true equilibrium. Thus, except at elevated temperatures where equilibrium is achieved more rapidly, their simulations are less likely to agree with field observations. Structural properties of certain minerals often preclude their formation in low-temperature, aqueous environments in favor of phases which nucleate more readily under these conditions. Thus, the fact that free energy calculations indicated that a ground water is oversaturated with corundum (Benson et a1. 1978, p. 36) is not meaningful when one considers the high-temperature reactions normally responsible for the existence of corundum.

Traditionally, petrologists have been interested in the crystalline minerals, almost to the exclusion of amorphic (i.e., amorphous like) minerals and surface coatings (Jenne 1977). The amorphic minerals (such as opal, allophane) are very important to mass transfer modeling because they are nearly ubiquitous and, as a group, dissolve more rapidly than their crystalline analogues. Since these amorphic phases are usually metastable, they are generally absent from the thermodynamic data base of reaction path models. Moreover, by being amorphic, individual members of this mineral group are likely to display a range of crystallinites with an accompanying range of solubility values. This is a significant complication. It suggests that an appropriate error estimate, based on the range of thermodynamic data for the amorphic minerals and on the uncertainties in the analytical values, would be a beginning to the development of reliable estimates for use in testing hypotheses of solubility equilibria.

The quality of analytical data, although not a limitation of the geochemical models themselves, severely limits our capability to interpret geochemical processes of natural waters. Available analyses are 1 imited both with respect to the analyzed constituents, to the accuracy 
and precision of the analyses, and to the measured physicochemical parameters (i.e., $\mathrm{pH}$ and $\mathrm{E}_{\mathrm{Pt}}^{\mathrm{H}}$ ).

The sampling plus analytical errors of constituents involved in complex solids are commoniy large enough that one is often forced to draw subjective conclusions relative to whether the equilibrium condition exists or not. Although the analytical measurement of dissolved constituents in water samples is commoniy the only step for which standard deviations are available, an adequate error estimate would have to include the sampling and sample preservation steps. The propagated standard deviation should be calculated in the speciation-solubility model and reported adjacent to the solid phase disequilibrium index. In the absence of adequate error terms, appropriate plotting techniques external to the model can permit objective estimation of the probability that an equilibrium condition exists (Nordstrom and Jenne 1977; Jenne, Ba11, Burchard, Vivit and Barks 1980).

A practical problem in reaction path modeling is the required data for certain physicochemical parameters of aquifers at hundreds to thousands of feet in depth. The partial pressure of a gas, such as $\mathrm{CO}_{2}$, may be several atmospheres in geothermal waters and is frequently above atmospheric pressure in confined aquifers. The exact partial pressure of $\mathrm{CO}_{2}$ is important because it affects the activity of $\mathrm{HCO}_{3}^{-}$and $\mathrm{CO}_{3}^{-2}$ in the water, hence the $\mathrm{pH}$ and the activity of $\mathrm{Ca}^{+2}$ and $\mathrm{Mg}^{+2}$ (due to formation of $\mathrm{CaHCO}_{3}^{+}, \mathrm{CaCO}_{3}^{0}, \mathrm{MgHCO}_{3}^{+}$, etc., species). This in turn affects the tendency of $\mathrm{Ca}$ - and $\mathrm{Mg}$-containing carbonates and silicates, etc., to precipitate as opposed to non-Ca and/or Mg-bearing silicates. Moreover, the partial pressures of one or more of the gases $\mathrm{O}_{2}, \mathrm{H}_{2}$ and $\mathrm{H}_{2} \mathrm{~S}$ generally need to be stipulated in order to permit the initial redox speciation. For the reaction path simulations to be meaningful, these variables must be accurately known because they place vital and interrelated constraints on the aqueous system.

\section{ADSORPTION MODELS}

Adsorption needs to be a component of both equilibrium and kinetic geochemical modeling. However, there are major limitations to the 
treatment of adsorption by any of the geochemical models described in this review. The REDEỌL2 model, for example, treats adsorption according to double-layer theory. However, because most adsorption modeling studies to date have been on pure phase substrates of silica, alumina, and either $\mathrm{Fe}_{2} \mathrm{O}_{3}$ or amorphous $\mathrm{Fe}\left(\mathrm{OH}_{3}\right)$, it has not been demonstrated that the double-layer approach works for heterogeneous substrates of earth material. The GEOCHEM model contains a mass-action exchange submodel for macro ions, in addition to the double-layer submodel. Mattigod and Sposito (1979) suggest that it is appropriate to use the mass-action model for reversible exchange of macro ions and the double-layer model for adsorption of trace concentrations, which commonly is at least partially irreversible. In contrast, the PHREEQE model handles ion exchange by fixing the activity ratio of the two exchanging ions (Parkhurst, Thorstenson and Plummer 1980). However, according to these authors, some ingenuity is required to handle the simultaneous exchange of more than two ions in such a model.

\section{KINETIC MODELS}

A major limitation of geochemical model ing is the absence of kinetic capabilities. If an application study requires knowledge of the water composition and/or changes in the mineral assemblage at equilibrium, then rates of reaction are not needed. However, most real world problems involve a time frame in which solid phase equilibrium is not a reasonable assumption. Many situations, especially temperature changes or mixing of waters, result in supersaturation of water with respect to solid phases. The rate at which precipitation actually occurs determines the extent and localization of mineral build up on rock fractures, in geothermal piping, and near the injection point for disposal wells, as well as the extent of movement of trace elements in surface and ground waters, and of radionuclides away from breached disposal sites. Obviously, if the kinetics of the major reactions were known as a function of temperature, the applicability of mass transfer model ing would be vastly greater. However, a considerable amount of rel iable kinetic data are required before kinetic submodels become a reality. 
The EQUILIB model of the Electric Power Research Institute is one of the very few models which takes speciation into account in dealing with precipitation of solid phases during flow of geothermal-type fluids (Shannon, Morrey and Smith 1977; Shannon and Lessor 1978). It is unique among the extant geochemical models in that it is linked to another model (FLOSCAL) which simulates the precipitation of selected solids (silica, calcite and several metal sulfides) according to kinetic rather than equilibrium constraints in the piping carrying geothermal water.

The kinetics of sorption may also be of significance. Unfortunately, few sorption studies contain enough data points as a function of time, particularly at the initial stages of each experiment, to permit kinetic analyses. Temperature may affect both the rate and extent of adsorption. However, little data exists. If the kinetics of sorption are shown to be important to water-earth material interactions, a three-way link will be necessary between speciation-solubility, kinetic and adsorption submodels to apply geochemical modeling to complicated real world problems. 


\section{CONCLUSIONS}

In a long review, Florence and Batley (1981) reach the following pessimistic conclusion: "for natural waters at least, the prospects of developing an analytical procedure which can measure the concentrations of all individual chemical species present in water are very bleak. Computer modeling techniques a im to perform this function, but until a great deal more reliable thermodynamic data become available, chemical modeling methods are unlikely to produce results which even approximate the true situation." It is impossible to measure all individual chemical species in natural waters; however, validated chemical models can approximate the true chemistries of many aqueous systems. In contrast to hydraulic and hydrologic model ing where users understood the need and performed verification (obtaining a similar modeling result with a different model) and validation, chemical modeling has been used by many who blatantly ignored the need for verification and validation of the models. Where appropriate "partial" validation has been carried out (Nordstrom and Jenne 1977; Jenne, Girvin, Burchard and Ball 1978; Jenne, Ba11, Burchard, Vivit and Barks 1980), a considerable amount of very useful information has been derived for aqueous systems. At this point in the development of the science of geochemical modeling, increased competence and validation of the models are much more important and timely than increased mathematical sophistication.

Thus, it is concluded that the major 1 imitations of geochemical modeling are: 1) limited verification and validation of models carried out to date; 2) lack of competence of models in terms of inclusion of known species and solids and of the known effects of temperature, ionic strength and solid solution; 3 ) inadequacy of the present theoretical foundation for single ion activity coefficients at intermediate and high ionic strengths; 4) lack of data on the temperature dependence of association constants of solutes and solubilities for solids; 5) lack of adequate theory and/or data on solid phases which form solid solution series; 6) lack of thermochemical data for some solutes and solids, especially association constants for natural metal-organic ligands; and 7) estimation and application of redox potentials. 
Model verification, a key to future model applications, is obtained by computing a similar result for a specified water composition with an entirely different model. This test was found very profitable following the addition of $U$ to WATEQ2 (Ba11, Jenne and Cantrel1 1981). Validation in turn is carried out by the modeling of both solubility experiments and the analyses of water samples from mines, ground waters and other sources. The combination of model verification and validation provides a gauge to ascertain the ability of those particular models to approximate the chemistries of natural waters and other aqueous systems.

A significant 1 imitation of many models is that they are incompetent; that is, they contain insufficient metals, ligands, complexes, and solids for the problem(s) to which they are applied. This major effect has been demonstrated for aqueous systems containing sulfide complexes (Jenne, Girvin, Burchard and Ball 1978; Jenne, Bal1, Burchard, Vivit and Barks 1980). Moreover, the effect a single complex may have is shown dramatically by Nordstrom, Plummer et al. (1979, Table VI), wherein the inclusion of $\mathrm{MgCl}$ and $\mathrm{CaCl}$ complexes in the GEOCHEM model which results in noticeably lower computed activities for $\mathrm{Mg}^{+2}$ and $\mathrm{Ca}^{+2}$ in comparison to those results computed by other models for the same water chemistry.

Some 1 imitations of geochemical models, such as lack of specific elements, are obvious by inspection. Other limitations, such as missing solid phases, may require searching and evaluation of geochemical and mineralogical literature. Still others will become apparent by failure of the models to simulate solutes and solids in specific applications. Therefore, these models must not be used blindly but each application should be viewed as a partial validation. Any questions and problems must be resolved in conjunction with each application in order to more closely predict useful results for waters and water-earth material interactions. Moreover, the reader need not share the pessimistic conclusion of Florence and Batley (1981) towards chemical modeling methods. Underlying this review is the concept that geochemical models provide a scientific framework for understanding and interpreting the chemistry of natural and polluted waters, as well as for predicting the results of anthropogenic contamination of natural waters. 


\section{REFERENCES}

Adams, F. 1971. "Ionic Concentrations and Activities in Soil Solutions." Soil Sci. Soc. Am. Proc. 35:420-426.

Ahlstrom, S. W., H. P. Foote, R. C. Arnett, R. C. Cole and R. J. Serne. 1977. Multicomponents Mass Transport Model: Theory and Numerical Impl ementation, (Discrete-Parcel-Random-WaTk version). BNWL-2127, Pacific Northwest Laboratory, Richland, Washington.

Andrew, R. W., K. E. Biesinger and G. E. Glass. 1977. "Effects of Inorganic Complexing on the Toxicity of Copper to Daphnia magna." Water Res. 11:309-315.

Ba11, J. W., E. A. Jenne and D. K. Nordstrom. 1979. "WATEQ2: A Computerized Chemical Model for Trace and Major Element Speciation and Mineral Equilibria for Natural Waters." In Chemical Modeling in Aqueous Systems, ed. E. A. Jenne, pp. 815-835. Amer. Chem. Soc. Symp. Series 93 .

Bal1, J. W., E. A. Jenne and M. W. Cantrel1. 1981. WATEQ3: A Geochemical Model with Uranium Added. U.S. Geol. Survey Water Res. Invest. (in press).

Bal1, J. W., D. K. Nordstrom and E. A. Jenne. 1980. Additional and Revised Thermochemical Data and Computer Code for WATEQ2--A Computerized Chemical Model for Trace and Major Element Speciation and Mineral Equilibria of Natural Waters. U.S. GeoT. Survey Water Res. Invest. 78-116.

Barnes, I., and F. E. Clarke. 1969. Chemical Properties of Ground Water and Their Corrosion and Encrustation Effect on WelTs. U.S. Geol. Survey Prof. Paper 498-D.

Bassett, R. L. 1979. "A Computer Model for Aqueous Organic Complexes in Natural Systems and Physiologic Fluids." In Trace Substances in Environmental Health-XIII, ed. D. D. Hemphill, pp. 195-207. University of Missouri, Columbia, Missouri.

Benson, L. V., C. L. Carnahan, J. A. Apps, C. A. Mouton, D. J. Corrigan, C. J. Frisch and L. K. Shomura. 1978. Basalt Alteration and Basalt-Waste Interaction in the Pasco Basin of Washington State, Final Report. LBL-8532, Lawrence Berkeley Laboratory, University of California, Berkeley, California.

Boulegue, J., and G. Michard. 1979. "Sulfur Speciation and Redox Processes in Reducing Environments." In Chemical Model ing in Aqueous Systems, ed. E. A. Jenne, pp. 25-50. Amer. Chem. Soc. Symp. Series 93 . 
Byrne, R. H., and D. R. Kester. 1976. "Solubility of Hydrous Ferric Oxide and Iron Speciation in Sea Water." Mar. Chem. 4:255-274.

Caram, H. S., and L. E. Schriven. 1976. "Nonunique Reaction Equilibria in Nonideal Systems." Chem. Eng. Sci. 31:163-168.

Davis, J. A., and J. 0. Leckie. 1979. "Speciation of Adsorbed Ions at the 0xide/Water Interface." In Chemical Modeling in Aqueous Systems, ed. E. A. Jenne, pp. 300-317. Amer. Chem. Soc. Symp. Series 93.

Department of Science and Industrial Research. 1964. Effects of Polluting Discharges in the Thames Estuary. Water Pollution Research Technical Paper No. 11, Her Majesty's Stationary Office, London, England.

Detar, D. F. 1969. Computer Programs for Chemistry, V. 2. W. A. Benjamin, New York, New York.

Deutsch, W. J. 1980. Geological Modeling of the Nuclear-Waste Repository System - A Status Report. PNL-3518, Pacific Northwest Laboratory, Richland, Washington.

Dufey, C., M. Petit, Y. Goblet and H. Laudelout. 1979. "Modilisation des Equilibres Physico-Chemiques de Change et de Precipitation dans les Systemes Sol-eau-electrolyte." Ann. Agron. 30:53-62.

Dutt, G. R. 1962. Qual ity of Percolating Water No. 1: Development of a Computer Program for Calculating the Ionic Composition of Percolating Water. Water Resource Center, Contribution No. 50, University of California, Davis, California.

Dutt, G. R., and L. D. Doneen. 1963. "Predicting the Solute Composition of the Saturation Extract from Soil Undergoing Salinization." Soil Sci. Soc. Am. Proc. 27:627-630.

Dyrssen, D., D. Jagner and F. Wengel in. 1968. Computer Calculation of Ionic Equilibria and Titration Procedures. John Wiley, New York, New York.

Fardy, J. J., and R. N. Sylva. 1978. SIAS, A Computer Program for the Generalized Calculation of Speciation in Mixed Metal-Ligand Systems. AAEC/E445, Lucas Heights, Australia.

Florence, T. M., and G. E. Batley. 1980. "Chemical Speciation in Natural Waters." CRC Critical Reviews in Analytical Chemistry 9:219-296.

Fordham, A. W. 1969. "Sorption and Precipitation of Iron on Kaol inite. I. Factors Involved in Sorption Equilibria." Aust. J. Soil Res. 7:185-197.

Fritz, B. 1975. Etude Thermodynamique et Simulation des Reactions entre Mineraux et Solutions Application a la Geochemie des Alterations et des Eaus continentales. Ph.D. Thesis, Univ. Louis Pasteur, Strausbourg, France. 
Garrels, R. M., and M. E. Thompson. 1962. "A Chemical Model for Sea Water at $25^{\circ} \mathrm{C}$ and One Atmosphere Total Pressure." Amer. Jour. Sci. 260:57-66.

Gear, C. W. 1971a. "The Automatic Integration of Ordinary Differential Equations." Communications of the ACM 14:176-179.

Gear, C. W. 1971b. "Algorithm 407-DIFSUD for Solution of Ordinary Differential Equations." Communications of the ACM 14:185-190.

Haas, J. L., Jr. 1974. PHAS20, A Program for the Simultaneous Multiple Regression of a Mathematical Model to Thermochemical Data. U.S. Geo1. Survey, NTIS Rep., AD-780 301.

Haas, J. L., Jr., and J. R. Fisher. 1976. "Simultaneous Evaluation and Correlation of Thermodynamic Data." Amer. J. Sci. 276:525-545.

Haas, J. L., Jr., G. P. Robinson, Jr., and B. S. Hemingway. 1980. Thermodynamic Tabulations for Selected Phases in the System CaO-Al $\mathrm{O}_{3}-\mathrm{SiO}_{2}-\mathrm{H}_{2} \mathrm{O}$. U.S. Geol. Survey Open File Report.

Harriss, D. K., V. R. Magnuson, D. K. Taylor and M. S. Sun. 1978. "REDEQL2-Program and Data-Base Modifications." Amer. Chem. Soc. Abstracts of Papers V176, September 1978, p. 113.

Helgeson, H. C. 1968. "Evaluation of Irreversible Reaction in Geochemical Processes Involving Minerals and Aqueous Solutions-1. Thermodynamic Relations." Geochim. Cosmochim. Acta. 32:853-977.

Helgeson, H. C. 1971. "Kinetics of Mass Transfer Among Silicates and Aqueous Solutions." Geochim. Cosmochim. Acta. 35:421-469.

Helgeson, H. C., T. H. Brown, A. Nigrini and T. A. Jones. 1970. "Calculation of Mass Transfer in Geochemical Processes Involving Aqueous Solutions." Geochim. Cosmochim. Acta. 34:569-592.

Helgeson, H. C., R. M. Garrels and F. T. Mackenzie. 1969. "Evaluation of Irreversible Reactions in Geochemical Processes Involving Minerals and Aqueous Solutions. II. Applications." Geochim. Cosmochim. Acta. 33:455-481.

Holdren, G. R., Jr. 1977. Distribution and Behavior of Manganese in the Interstitial water of Chesapeake Bay Sediments During Early Diagenes is. Ph.D. Thesis, Johns Hopkins University, Baltimore, Maryland.

Ingle, S. E., M. D. Schuldt and D. W. Schults. 1978. REDEQL2.EPA. A Computer Program for Chemical Equilibriums in Aqueous Systems. EPA600/3-78,024. Environmental Protection Agency. 
Ingri, N., W. Kakolowiez, L. G. Sillen and B. Warnquist. 1967. "Highspeed Computers as a Supplement of Graphical Methods-V. Haltfall, a General Program for Calculating the Composition of Equilibrium Mixtures." Talanta 114:1261-1286.

INTERA Environmental Consultants. 1979. Revision of the Documentation for a Model for Calculating Effects of Liquid Waste Disposal in Deep Saline Aquifers. U.S. Geol. Survey water Res. Invest. 79-96.

Jackson, G. A., and J. J. Morgan. 1978. "Trace-Metal Chelator Interactions and Phytoplankton Growth in Sea Water Media: Theoretical Analysis and Comparison with Reported Observations." Limnol. Ocean. 23:268-282.

Jenne, E. A. 1977. "Trace Element Sorption by Sediments and Soils. Sites and Processes." In Molybdenum in the Environment, Volume 2, ed. W. Chappe 11 and K. Petersen, pp. 425-553. M. Dekker, New York, New York.

Jenne, E. A. 1979. "Chemical Modeling - Goals, Problems, Approaches and Priorities." In Chemical Modeling in Aqueous Systems, ed. E. A. Jenne, pp. 1-21. Amer. Chem. Soc. Symp. Series 93.

Jenne, E. A., J. W. Ba11, J. M. Burchard, D. V. Vivit and J. H. Barks. 1980. "Geochemical Modeling: Apparent Solubility Controls on Ba, $\mathrm{Zn}, \mathrm{Cd}, \mathrm{Pb}$ and $\mathrm{F}$ in Waters of the Missouri Tri-State Mining Area." In Trace Substances in Environmental Health-XIV, ed. D. D. Hemphi11, pp. 353-361. University of Missouri, Columbia, Missouri.

Jenne, E. A., D. C. Girvin, J. W. Ball and J. M. Burchard. 1978. "Inorganic Speciation of Silver in Natural Waters - Fresh to Marine." In Environmental Impacts of Nucleating Agents Used in Weather Mod ification Programs, ed. D. A. Klein, Chapter 4, pp. 41-61. Dowden, Hutchinson and Ross, Stroudsburg, Pennsylvania.

Jenne, E. A., and S. N. Luoma. 1977. "The Forms of Trace Elements in Soils, Sediments, and Associated Waters: An Overview of Their Determination and Biological Availability." In Biological Implications of Metals in the Environment, ed. R. E. Wildung and H. Drucker, pp. 110-143. CONF-750929, NTIS, Springfield, Virginia.

Jenne, E. A., and A. H. Truesde11. 1973. "Identification of Recharge Sources and an Evaluation of Possible Water Quality Effects of Artificial Recharge as Indicated by Mineral Equilibria Calculations." In Artificial Recharge in the White Water River Area, Palm Springs, California, ed. S. J. Tyley, pp. 29-43. U.S. Geol. Survey Open File Report.

Kester, D. R., R. H. Byrne, Jr. and Y. J. Liang. 1975. "Redox Reactions and Solution Complexes of Iron in Marine Systems." In Marine Chemistry in the Coastal Environment, ed. T. M. Church, pp. 56-79. Amer. Chem. Soc. Symp. Series 18. 
Kharaka, Y. K., and I. Barnes. 1973. SOLMNEQ: Solution-Mineral Equilibrium Computations. U.S. Geol. Survey water Res. Invest. 73-002, NTIS PB-215 899.

Lafon, G. M. 1969. Some Quantitative Aspects of the Chemical Evaluation of the Oceans. Ph. D. Thesis, Northwestern University, Evanston, I17 ino is.

Langmuir, D. 1978. "Uranium Solution-Mineral Equilibria at Low Temperatures with Applications to Sedimentary Ore Deposits." Geochim. Cosmochim. Acta. 42:547-569.

Leggett, D. J. 1977. "Machine Computation of Equilibrium Concentrations Some Practical Considerations." Talanta 24:535-542.

Lindberg, A., and C. Borno. 1975. "Calculation of Calcium Carbonate-Carbon Dioxide Equilibrium in Water and Mixtures of Water." Verh. Internat. Verun. Limnol. 19:1511-1517.

MacCarthy, P., and G. C. Smith. 1979. "Stability Surface Concept: A Quantitative Model for Complexations in Multiligand Mixtures." In Chemical Model ing in Aqueous Systems, ed. E. A. Jenne, pp. 201-222. Amer. Chem. Soc. Symp. Series 93.

Magnuson, V. R., D. K. Harriss, M. S. Sun, D. K. Taylor and G. E. Glass. 1979. "Relationships of Activities of Metal-Ligand Species to Aquatic Toxicity." In Chemical Modeling in Aqueous Systems, ed. E. A. Jenne, pp. 636-656. Amer. Chem. Soc. Symp. Series 93.

Marcus, Y. 1977. "The Activities of Potassium Chloride and Water in Dead Sea Brine." Geochim. Cosmochim. Acta. 41:1739-1744.

Mattigod, S. V., and G. Sposito. 1978. "Improved Method for Estimating the Standard Free Energies of Formation $\left(\Delta G_{f_{1}}^{\circ} 298.15\right)$ of Smectites."
Geochim. Cosmochim. Acta. $42: 1753-1762$.

Mattigod, S. V., and G. Sposito. 1979. "Chemical Modeling of Trace Metal Equilibria in Contaminated Soil Solutions Using the Computer Program GEOCHEM." In Chemical Modeling in Aqueous Systems, ed. E. A. Jenne, pp. 837-856. Amer. Chem. Soc. Symp. Series 93.

Mattigod, S. V., A. S. Gibali and A. L. Page. 1979. "Effects of Ionic Strength and Ion Pair Formation on the Adsorption of Nickel by Kaolinite." Clays and Clay Minerals 27:411-416.

McDuff, R. E., and F. M. M. Morel. 1973. Description and Use of the Chemical Equilibrium Program REDEQL2. Tech. Report EQ-73-02. Keck Lab., Environ. Eng. Sci., Cal. Tech., Pasadena, California.

Miller, D. G., A. J. Pivinskii and R. Yamauchi. 1977. The Use of Geochemical-Equilibrium Computer Calculations to Estimate Precipitafrom Geothermal Brines. UCRL-52197, Lawrence Livermore Laboratory Report, Livermore, CaTifornia. 
More1, F., R. E. McDuff and J. J. Morgan. 1973a. Modeling of Adsorption of Solutes on Solid Surfaces as Part of Chemical Equilibrium Computations. Tech. Report EQ 73-01. Keck Lab., CaT. Tech., Pasadena, California.

Morel, F., R. E. McDuff and J. J. Morgan. 1973b. "Interactions and Chemostasis in Aquatic Chemical Systems: Role of pH, pE, Solubility and Complexation." In Trace Metals and Metal-Organic Interactions in Natural Waters, pp. 157-199. Ann Arbor Sci. Pub.

Morel, F., and J. J. Morgan. 1972. "A Numerical Method for Computing Equilibria in Aqueous Chemical Systems." Environ. Sci. Tech. $6: 58-67$.

Nordstrom, D. K., and E. A. Jenne. 1977. "Fluorite Solubility Equilibria in Selected Geothermal Waters." Geochim. Cosmochim. Acta. 41:175-188.

Nordstrom, D. K., E. A. Jenne and J. W. Ball. 1979. "Redox Equilibria of Iron in Acid Mine Waters." In Chemical Modeling in Aqueous Systems, ed. E. A. Jenne, p. 51-80. Amer. Chem. Soc. Symp. Series 93.

Nordstrom, D. K., L. N. Plummer, T. M. L. Wigley, T. J. Wolery, J. W. Ball, E. A. Jenne, et al. 1979. "A Comparison of Computerized Chemical Models for Equilibrium Calculations in Aqueous Systems." In Chemical Model ing in Aqueous Systems, ed. E. A. Jenne, pp. 815-835. Amer. Chem. Soc. Symp. Series 93.

Onishi, Y. 1977. Mathematical Simulation of Sediment and Radionuclide Transport in the Columbia River. BNWL-2228, Pacific Northwest Laboratory, Richland, Washington.

Onishi, Y., A. R. 0lsen, R. B. Ambrose and J. W. Faleo. 1979. "Pesticide Transport Modeling in Streams." Paper presented at the National Symposium on Hydraulic Transport in Modeling, December 10, 1979, New Orleans, Louisiana.

Onishi, Y., and S. E. Wise. 1978. Mathematical Simulation of Transport of Sediment and Kepone in the James River Estuary. PNL-2731, Pac if ic Northwest Laboratory, Richland, Washington.

Oster, J. P., and B. L. McNeal. 1971. "Computation of Soil Solution Composition Variation with Water Content for Desaturated Soil." Soil Sci. Soc. Amer. Proc. 35:436-442.

Othmer, H. G. 1976. "Nonuniqueness of Equilibria in Closed Reacting Systems." Chem. Eng. Sci. 31:993-1003.

Paces, T. 1973a. "Active Mineral Surfaces: Origin and Possible Effects on Trace Elements in Natural Water Systems." In Trace Substances in Environmental Health-VI, ed. D. D. Hemphill, pp. 361-368. University of Missouri, Columbia, Missouri. 
Paces, T. 1973b. "Steady-State Kinetics and Equilibrium Between Ground Water and Granitic Rock." Geochim. Cosmochim. Acta. 37:2641-2663.

Pagenkopf, G. K. 1978. Predicted Trace Metal Concentrations in Sal ine Seep Waters. Montana State University, Bozeman, Report NUOWRRC, Report No. 9.

Parkhurst, D. L., D. C. Thorstenson and L. N. Plummer. 1980. PHREEQE A Computer Program for Geochemical Calculations. U.S. GeoT. Survey Water Res. Invest. 80-96.

Paulson, A. J. 1978. Potentiometric Studies of Cupric Hydroxide Complexation. M.S. Thesis, University of Rhode Island, Kingston, Rhode Island.

Paulson, A. J. 1980. "Copper (II) in Hydrolysis in Aqueous Solution." J. Soln. Chem. 9:269-277.

Perrin, D. D. 1965. "Multiple Equilibria in Assemblages of Metal Ions and Complexing Species: A Model for Biological Systems." Nature 206:170-171.

Perrin, D. D. 1977. "Recent Applications of Digital Computers in Analytical Chemistry." Talanta 24:339-345.

Perrin, D. D., and I. G. Sayce. 1967. "Computer Calculation of Equilibrium Concentrations in Mixtures of Metal Ions and Complexing Species." Talanta 14:833-842.

Plummer, L. N. 1975. "Mixing of Sea Water with Calcium Carbonate Ground Water." Mem. Geol. Soc. Am. 142:219-236.

P1 ummer, L. N., D. L. Parkhurst and D. R. Kosiur. 1975. MIX2: A Computer Program for Model ing Chemical Reactions in Natural Water. U.S. Geol. Survey Water Res. Invest. 75-61.

Plummer, L. N., B. F. Jones and A. H. Truesdel1. 1976. WATEQF-A FORTRAN IV Version of WATEQ, A Computer Program for Calculating Chemical Equilibrium of Natural Waters. U.S. Geol. Survey Water Res. Invest. Rep. 76-13.

Potter II, R. W. 1977. "An Electrochemical Investigation of the System Copper-Sulfur." Econ. Geol. 72:1524-1542.

Potter II, R. W., and J. L. Haas, Jr. 1978. "Models for Calculating Density and Vapor Pressure of Geothermal Brines." U.S. Geol. Survey J. Res. $6: 247-257$.

Potter, II, R. W., J. M. Thompson, M. A. Clynne and V. L. Thurmond. 1979. "Equilibrium, Kinetic and Chromatographic Controls of the Solution Composition Obtained During the In Situ Leaching of a Uranium Ore Body." In Chemical Model ing in Aqueous Systems, ed. E. A. Jenne, pp. 761-769. Amer. Chem. Soc. Symp. Series 93. 
Reardon, E. J., and P. Fritz. 1978. "Computer Modeling of Ground Water ${ }^{13} \mathrm{C}$ and ${ }^{14} \mathrm{C}$ isotope compositions." J. Hydrology 36:201-224.

Rosenblatt, D. H., E. P. Meier and M. J. Sma11. 1975. Aqueous Halogen Equilibria: Case I. Halogen in Pure Water. Report TR7506, U.S. Army Medical Bioengineering Research and Development Laboratory, Fort Detrick, Frederick, Maryland.

Routson, R. C., and R. J. Serne. 1972. One-dimensional Model of the Movement of Trace Radioactive Solute Through Soil Columns: The Percol Model. BNWL-1718, Pacific Northwest Laboratory, Richland, Washington.

Rubin, J., and R. V. James. 1973. "Dispersion Affected Transport of Reacting Solutes in Saturated Porous Media: Galerkin Method Applied to Equilibrium-Controlled Exchange in Unidirectional Steady Water Flow." Water Resources Research 9:1332-1356.

Runnel1s, D. D., and R. D. Lindberg. 1981. "Hydrogeochemical Exploration for Uranium Ore Deposits: Use of the Model WATEQFC." Jour. Geochem. Exploration (in press).

Runnells, D. D., R. Lindberg, S. L. Lueck and M. Markos. 1980. Applications of Computer Modeling to the Genesis, Exploration, and In Situ Mining of Uranium and Vanadium Deposits. New Mexico Bureau of Mines and Mineral Resources Memoir 38, Grants Uranium Be1t, pp. 355-367.

Shannon, D. W., and D. L. Lessor. 1978. "Brine Chemistry and Combined Heat/Mass Transfer." In Proc. 22nd Geothermal Conference and Workshop. Electric Power Res. Inst. WS-78-97, Palo Alto, California.

Shannon, D. W., J. R. Morrey and R. P. Smith. 1977. "Use of a Chemical Equilibrium Model Computer Code to Analyze Seale Formation and Corrosion in Geothermal Brines." In Proc. Internat'1. Symp. on 0ilfield and Geothermal Chemistry, p. 21-36. CONF-770609.

Sposito, G., and S. V. Mattigod. 1979. GEOCHEM: A Computer Program for the Calculation of Chemical Equilibria in Soil Solutions and other Natural Water Systems. Dept. Soil Environmental Sciences, University of California/Riverside, Riverside, California.

Sposito, G., A. L. Page and M. Frink. 1980. Effects of Acid Precipitation on Soil Leachate Quality: Computer Calculations. EPA-600/3-80-015, Environmental Protection Agency.

Sposito, G., A. L. Page, S. V. Mattigod, M. Frink, W. Toben and R. Norris. 1979. Trace Metal Speciation in Saline Water Affected by Geothermal Brines. Final Technical Report, Dept. Soil and Environmental Sciences, University of California/Riverside, Riverside, California. 
Tardy, Y., and R. M. Garrels. 1974. "A Method of Estimating the Gibbs Energies of Formation of Layer Silicates." Geochim. Cosmochim. Acta. 38:1101-1116.

Thomann, R. V., D. J. O'Conner and D. M. Di Toro. 1970. "Model ing Nitrogen and Algal Cycles in Estuaries." Paper presented at the Fifth International Conference on Water Pollution Resesarch, Paper No. III-9(2):9.1-14, July-August 1970, San Francisco, California.

Thorstenson, D. C., and L. N. Plummer. 1977. "Equilibrium Criteria for Two-Component Solids Reacting with Fixed Composition in an Aqueous Phase--Example: The Magnesium Calcites." Amer. Jour. Sci. 277:1203-1223.

Thrailkill, J. 1970. Solution Geochemistry of the Water of Limestone Terrains. University of Kentucky Water Res. Inst. Res. Rep. 19.

Tripathi, V. S. 1979. Comments on "Uranium Solution-Mineral Equilibria at Low Temperatures with Applications to Sedimentary Ore Deposits." Geochim. Cosmochim. Acta. 43:1991.

Truesdel1, A. H., and B. F. Jones. 1973. WATEQ, A Computer Program for Calculating Chemical Equilibria of Natural Waters. NTIS-PB2-20464, Springfield, Virginia.

Truesdel1, A. H., and B. F. Jones. 1974. "WATEQ, A Computer Program for Calculating Chemical Equilibria of Natural Waters." U.S. Geol. Survey J. Res. 2:233-274.

Van Breeman, N. 1973. "Calculation of Ionic Activities in Natural Waters." Geochim. Cosmochim. Acta. 37:101-107.

Van Luik, A. C., and J. J. Jurinak. 1979. "Equilibrium Chemistry of Heavy Metals in Concentrated Electrolyte Solution." In Chemical Model ing in Aqueous Systems, ed. E. A. Jenne, pp. 683-710. Amer. Chem. Soc. Symp. Series 93 .

Von Zeggeren, F., and S. H. Storey. 1970. The Computation of Chemical Equilibria. Cambridge Univ. Press, London, England.

Vuceta, J., and J. Morgan. 1978. "Chemical Model ing of Trace Metals in Fresh Waters: Role of Complexation and Adsorption." Environ. Sci. Tech. 12:1302-1309.

Westa11, J. C., J. L. Zachary and F. M. M. Morel. 1976. MINEQL, A Computer Program for the Calculation of Chemical Equilibrium Composition of Aqueous Systems. Tech. Note 18, Dept. Civil Eng., Massachusetts Institute of Technology, Cambridge, Massachusetts.

Whitfield, M. 1975a. "An Improved Specific Interaction Model for Sea Water at $25^{\circ} \mathrm{C}$ and 1 Atmosphere Total Pressure." Mar. Chem. 3:197-213. 
Whitfield, M. 1975b. "The Extension of Chemical Models for Sea Water to Include Trace Components at $25^{\circ} \mathrm{C}$ and 1 Atmosphere Pressure." Geochim. Cosmochim. Acta. 39:1545-1557.

Wigley, T. M. L. 1977. WATSPEC: A Computer Program for Determining the Equilibrium Speciation of Aqueous Solutions. Brit. Geomorph. Res. Group Tech. Bull. 20.

Williams, G. J., and J. B. Hinwood. 1976. "Two Dimensional Mathematical Water Quality Model." Jour. Environmental Eng. Div. ASCE, 149-163.

Wolery, T. J. 1978. Some Chemical Aspects of Hydrothermal Processes at Mid-oceanic Ridges--A Theoretical Study. I. Basalt-Sea Water Reaction and Chemical Cycling Between the Oceanic Crust and the Oceans. II. Calculation of Chemical Equilibrium Between Aqueous Solutions and Minerals. Ph.D. Thesis, Northwestern University, Evanston, Illinois.

Wolery, T. J. 1979. Calculation of Chemical Equilibrium Between Aqueous Solution and Minerals. The EQ3/6 Software Package. UCRL-52658, Lawrence Livermore Laboratory, Livermore, California.

Zeleznik, F. J., and S. Gordon. 1968. "Calculation of Complex Chemical Equilibria." Ind. Eng. Chem. 60:27-57. 


\section{ACKNOWLEDGMENTS}

This research was supported by the Waste/Rock Interactions Technology Program (WRIT) conducted by Pacific Northwest Laboratory. The WRIT Program is sponsored by the Office of Nuclear Waste Isolation, managed by Battelle Memorial Institute for the U.S. Department of Energy under Contract DE-AC06-76RLO 1830.

The thorough review by Kenneth Krupka, helpful review suggestions made by Donald Girvin, Jeffrey Serne, William Deutsch and Pam Partch, as well as manuscript editing by Naomi Sherer and typing by Sharon Lepel are appreciated. 

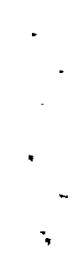


\section{DISTRIBUTION LIST}

No. of Copies

OFFSITE

A. A. Churm

DOE Patent Division

9800 South Cass Avenue

Argonne, IL 60439

27 DOE Technical Information Center

Don Alexander

U.S. Nuclear Regulatory Commission

MS 905-SS

High Level Waste Tech. Development

Washington, DC 20555

Argonne National Laboratory

Reference Library

9800 South Cass Avenue

Argonne, IL 60439

10 Battelle Memorial Institute

Office of Nuclear Waste Isolation

$505 \mathrm{King}$ Avenue

Columbus, $\mathrm{OH} 43201$

Attn: Beverly Rawles

Gary Beall

Radian Corporation

8500 Shoal Creek

Austin, TX 78766

Dr. John Bird

Geology Department

Corne 11 University

Ithaca, NY 14853
No. of

Copies

Ernest Bondietti

Environmental Sciences Division Oak Ridge National Laboratory

Bldg. 1505

Oak Ridge, TN 37830

A. Brandstetter

Office of Nuclear Waste Isolation

Battelle Memorial Institute

505 King Avenue

Columbus, $\mathrm{OH} 43201$

Brookhaven National Laboratory

Reference Section

Information Division

Upton, Long Is land, NY 11973

Harry C. Burkholder

Office of Nuclear Waste Isolation

Battelle Memorial Institute

505 King Avenue

Columbus, $\mathrm{OH} 43201$

J. L. Burnett

DOE Office of Basic Energy

Sciences

Washington, DC 20545

Wayne Carbiener

Office of Nuclear Waste

Isolation

Battelle Memorial Institute

505 King Avenue

Columbus, $\mathrm{OH} 43201$

H. Clyde Claiborne

Oak Ridge National Laboratory

P.0. Box $X$

Oak Ridge, TN 37830 
No. of

Copies

Peter Columbo

Brookhaven National Laboratory

Nuclear Waste Management Group

Upton, NY 11973

Carl R. Cooley

DOE Division of Waste Isolation

Washington, DC 20545

Jared Davis

U.S. Nuclear Regulatory

Commission

Washington, DC 20555

Les Dole

Oak Ridge National Laboratory

P.0. Box X

Oak Ridge, TN 37830

Jim 0. Duguid

Office of Nuclear Waste Isolation

Battelle Memorial Institute

505 King Avenue

Columbus, $\mathrm{OH} 43201$

Environmental Protection Agency

Office of Radiation Programs

Technical Assessment Division Aw559

Washington, DC 20460

Warren Eister

DOE Division of Waste Isolation

Washington, DC 20545

Bruce R. Erdal

Los Alamos Scient ific Laboratory

CNC-11, MS-514

Los Alamos, NM 87545

Sherman Fried

Argonne National Laboratory

9700 South Cass Avenue

Argonne, IL 60439
No. of

Copies

A. Friedman

Argonne National Laboratory

9700 South Cass Avenue

Argonne, IL 60439

Alex Gancarz

Los Alamos Scientific Laboratory

CNC-11, Mailstop 514

Los Alamos, NM 87545

Robert G. Garvin

E. I. duPont deNemours Co.

Savannah River Laboratory

Aiken, SC 29801

Richard L. Hahn

Oak Ridge National Laboratory

P.0. Box $X$

Oak Ridge, TN 37830

R. J. Hall

Office of Nuclear Waste Isolation

Battelle Memorial Institute

505 King Avenue

Columbus, $\mathrm{OH} 43201$

Mark Harwe 11

P.0. Box 667

Canon Beach, OR 97110

Colin A. Heath

DOE Division of Waste Isolation

Washington, DC 20545

Peter Hoffman

Office of Nuclear Waste

Isolation

505 King Avenue

Columbus, $\mathrm{OH} 43201$

H. D. Holland

Dept. of Geological Sciences

Harvard University

Cambridge, MA 02138 
No. of

Copies

Norman Hubbard

Office of Nuclear Waste Isolation

Battelle Memorial Institute

505 King Avenue

Columbus, $\mathrm{OH} \quad 43201$

J. K. Johnstone

Sandia Laboratories

Albuquerque, NM 87107

G. R. Kilp

Advanced Energy System Division Westinghouse Electric Corp. P.0. Box 10864

Pittsburgh, PA 15236

John F. Kircher

Office of Nuclear Waste Isolation

Battelle Memorial Institute

505 King Avenue

Columbus, $\mathrm{OH} 43201$

Lawrence Berkeley Laboratory

Reference Library

University of California

Berkeley, CA 94720

Lawrence Livermore Laboratory

Reference Library

P.0. Box 808

Livermore, CA 94550

Tom Longo

DOE Division of Waste Isolation

Washington, DC 20545

Los Alamos Scientific Laboratory

Reference Library

P.0. Box 1663

Los Alamos, NM 87544

Richard W. Lynch

Manager, Department 4530

Sandia Laboratories

P.0. Box 5800

Albuquerque, NM 87185
No. of

Copies

J. B. Martin

Asst. Director for Radioactive Waste Mgmt. Branch

NRC Division of Materials and Fuel Cycle Facility Licensing Washington, DC 20555

Mart in A. Molecke

Nuclear Waste Experimental

Programs

Division 4512

Sandia Laboratories

Albuquerque, NM 87185

J. E. Monsees

Office of Nuclear Waste Isolation

Battelle Memorial Institute

505 King Avenue

Columbus, $\mathrm{OH} 43201$

J. B. Moody

Office of Nuclear Waste Isolation

Battelle Memorial Institute

$505 \mathrm{King}$ Avenue

Columbus, $\mathrm{OH} 43201$

Jim P. Murray

Harvard University

Pierce Hall

Cambridge, MA 02138

Jeff 0 . Neff

DOE Columbus Program Office

505 King Avenue

Columbus, $\mathrm{OH} 43201$

Edward Norr is

Los Alamos Scientific Laboratory

Group CNC-11 MS-514

P.0. Box 1663

Los Alamos, NM 87545

E. J. Nowak

Sandia Laboratory

Division 5824

Albuquerque, NM 87131 
Oak Ridge National Laboratory

Central Research Library Document Reference Section

Oak Ridge, TN 37830

Edward 0'Donne 11

U.S. Nuclear Regulatory

Commission

Office of Standards Development Washington, DC 20555

W. M. Pardue

Office of Nuclear Waste Isolation

Battelle Memorial Institute

505 King Avenue

Columbus, $\mathrm{OH} 43201$

George A. Parks

Stanford University

Department of Applied Earth

Sciences

Stanford, CA 94305

L. D. Ramspott

Lawrence Livermore Laboratory

P.0. Box 808

Livermore, CA 94550

Gary A. Robbins

Department of Geology

Texas A\&M University

College Station, TX

R. A. Robinson

Office of Nuclear Waste Isolation

Battelle Memorial Institute

505 King Avenue

Columbus, $\mathrm{OH} 43201$

Savannah River Laboratory

Reference Library

Aiken, SC 29801
Martin Seitz

Argonne National Laboratory

9700 South Cass Avenue

Argonne, IL 60439

Robert Silva

Lawrence Berkeley Laboratory

University of California

One Cyclotron Road

Building 70A/1160

Berkeley, CA 94720

David B. Stewart

National Center 959

U.S. Geological Survey

Reston, VA 22092

H. Weed

Lawrence Livermore Laboratory

P.0. Box 808, MS-L233

Livermore, CA 94550

William B. White

Materials Research Laboratory Pennsylvania State University

University Park, PA 16802

R. F. Williams

Electric Power Research Institute

3412 Hillview Avenue

P.0. Box 10412

Palo Alto, CA 94303

W. A. Williams

Office of Radiation Programs

Environmental Protection Agency

Washington, DC 20460

Wilste Library

U.S. Nuclear Regulatory

Commission

Washington, DC 20555

T. J. Wolery

Lawrence Livermore Laboratory

P.0. Box 808

Livermore, CA 94550 
No. of

Copies

H. Tom Yolken

National Bureau of Standards

Physics Building/B320

Washington, DC 20234

\section{ONSITE}

3 DOE Richland Operations Office

H. E. Ransom

P. A. Craig (2)

5 Rockwe 11 Hanford Operations

G. S. Barney

0. Brown

M. J. Smith

M. I. Wood

B. J. Wood

Hanford Engineering Development Laboratory

R. J. Cash

104

\section{Pacific Northwest Laboratory}

L. L. Ames

D. J. Bradley

T. D. Chikalla

M. 0. Cloninger

D. G. Coles

W. J. Deutsch

F. H. Dove

A. R. Felmy

K. E. Harding (4)
No. of

Copies

F. N. Hodges

J. H. Jarrett

E. A. Jenne (50)

M. R. Kreiter

K. M. Krupka

W. L. Kuhn

D. E. Larson

J. L. McElroy/

R. E. Nightingale

G. L. McVay

R. D. Nelson/W. A. Ross/ 0. F. Hill

C. R. Palmer/R. 0. Lokken/

A. D. Chockie/

G. B. Mellinger

A. M. Platt

R. A. Peters

D. Rai

J. F. Relyea

J. M. Rusin/R. P. May

J. L. Ryan

R. J. Serne

J. W. Shade

J. A. Stott lemyre

R. G. Strickert

J. L. Swanson

R. P. Turcotte/D. M. Strachen

N. H. Uziemblo

B. E. Vaughan

R. W. Westerman

E. J. Whee lwright

R. E. Wildung

Water and Land Resources Library (10)

Technical Information Library (3)

Publishing Coordination (2) 
- 